\title{
Optimization of Roasting Conditions on the Bioactive Compounds and their Antioxidant Power from Opuntia fiscus-Indica Seeds using Response Surface Methodology (RSM)
}

\author{
Chakir El Guezzane ${ }^{(\mathbb{D})}$, Hamza El Moudden ${ }^{1 \mathbb{D}}$, Hicham Harhar ${ }^{1}{ }^{(\mathbb{D})}$, Ismail Warad ${ }^{2} \mathbb{D}$, Abdelkabir \\ Bellaouchou $^{1}$ (i) , Abdallah Guenbour ${ }^{1}$ (D) , Abdelkader Zarrouk ${ }^{1, *(D)}$, Mohamed Tabyaoui ${ }^{1}$ (D) \\ 1 Laboratory of Materials,Nanotechnology and Environment, Faculty of Sciences, Mohammed V University, P.O. Box 1014 \\ Agdal-Rabat, Morocco \\ 2 Department of Chemistry and Earth Sciences, PO Box 2713, Qatar University, Doha, Qatar \\ * Correspondence: azarrouk@gmail.com;
}

Scopus Author ID 36125763200

Received: 14.09.2020; Revised: 25.10.2020; Accepted: 26.10.2020; Published: 31.10.2020

\begin{abstract}
This work is aimed to optimize the effects of different roasting factors on the bioactive compound's antioxidant capabilities of opuntia ficus indica seeds by using DPPH and ABTS assays. The Box-Behnken design (BBD) was applied to optimize the roasting temperature (X1:60-200 $\left.{ }^{\circ} \mathrm{C}\right)$, roasting time (X2:10-50 min), and extraction time $\left(\mathrm{X}_{3}: 3-6 \mathrm{~h}\right)$. The optimal conditions of roasting applied in order to optimize the greatest content of the responses were: TPC (Total Phenolic Content): $\mathrm{X} 1: 200{ }^{\circ} \mathrm{C}, \mathrm{X} 2: 50 \mathrm{~min}$, and $\mathrm{X}_{3}: 5.49 \mathrm{~h}$ with $103.5 \pm 0.76 \mathrm{GAE} / \mathrm{g}$ extract experimental response, TFC (Total Flavonoids content): $\mathrm{X} 1: 200^{\circ} \mathrm{C}, \mathrm{X} 2: 50 \mathrm{~min}$, and $\mathrm{X}_{3}: 3.16 \mathrm{~h}$ with $104.29 \pm 0.54 \mathrm{mg}$ QE/g extract experimental response, TTC (Total Condensed Tannins Content): X1: $200^{\circ} \mathrm{C}, \mathrm{X} 2: 50 \mathrm{~min}, \mathrm{X}_{3}: 6 \mathrm{~h}$ with 10,16 $\pm 0.89 \mathrm{mg}$ QAE/g extract experimental response, TSC ( Total Sugars Content ): X1: $60^{\circ} \mathrm{C}, \mathrm{X} 2: 50$ min, $X_{3}: 5.12 \mathrm{~h}$ with $40.35 \pm 0.99 \mathrm{mg}$ D-Glu E/g extract an experimental response. The maximal antioxidant power by DPPH and ABTS assays was recorded at a strong temperature of roasting. Moreover, the significant correlations were obtained by the principal component analysis (PCA), the first step, between the bioactive compounds, and on the second step, between their antioxidant capacities (DPPH, ABTS). Hierarchical Cluster Analysis (HCA) classified extracts into three clusters on the basis of measured antioxidant activity characteristics. Therefore, the result of this work indicates that roasted Opuntia ficus Indica seeds could be used as a significant human nutrient.
\end{abstract}

Keywords: Seeds; Box-Behnken design; roasting, antioxidant activity; polyphenols; DPPH; ABTS;Opuntia ficus indica.

(C) 2020 by the authors. This article is an open-access article distributed under the terms and conditions of the Creative Commons Attribution (CC BY) license (https://creativecommons.org/licenses/by/4.0/).

\section{Introduction}

Opuntia ficus - Indica is notorious under the name of prickly pear; it belongs to the family of Cactaceae. It adapts well to arid and semi-arid conditions. It is also well spread in the Mediterranean region, Mexico, and South Africa [1-3]. Additionally, it is an important plant in the agricultural economies and has been cultivated since old periods [4,5]. Furthermore, prickly pears have been used for a long time in traditional medicine. Recent research showed that domestic use of seeds, fruits, and vegetables had a strong positive correlation in the prevention of modern diseases such as diabetes, cancer, and arthritis [6,7]. The seeds are 
considered an essential source of nutritional values, such as flavonoids, polyphenols, fatty acids, and tannins, and their quantities are higher than in the fruit pulp[8]. In addition, they contain about 10 to $15 \%$ of the edible pulp and are often discarded as waste after extraction from the pulp [9]. Roasting the seeds has numerous benefits such as promoting flavor, aroma, change the color and texture of roasted seeds, as well as eliminating unwanted microorganisms and food contaminants. Furthermore, they are known for deactivating enzymes that can accelerate the loss of nutrients and extending the duration of product life. In order to preserve the beneficial constituents of the seeds, the duration and temperature of roasting are considered the most important conditions [10-12]. Moreover, a number of research investigations have shown that the phenolic profile of different edible ingredients can be made of more health benefits by increasing their antioxidant capabilities [11]. This beneficial result is dependent on the grain considered and the roasting conditions utilized. During the roasting, the antioxidant compounds can degrade, and the formation of new products named Maillard reaction products (MRP) is observed. Degradation can influence antioxidant significantly [13]. Several studies assessed the effects of roasting on bioactive composition and antioxidant capabilities from various vegetable plants and seeds[14,15]. And it was found that the optimization of roasting conditions for seeds from Opuntia ficus Indica can significantly improve the antioxidant activity. Therefore systematic and precise optimization protocols for extraction and roasting conditions are required to maintain the bioactive and antioxidant activities precisely. Response Surface Methodology (RSM) is a statistical technique used to optimize the suggested protocols as it uses quantitative variables (roasting parameters) with an adequate experimental design to evaluate the effects of these parameters and their inherent interaction. Box-Behnken design (BBD) is an RSM capable of the generation of a mathematical model, taking into account the effect of the potential interactions among the factors under testing while keeping the number of experiments to be carried out minimized [14,16]. Therefore, the objective of the present work is to apply the RMS methodology and to investigate the effect of several factors such as the temperature of the roasting process, the duration of roasting, and the duration of extraction in order to optimize TCP (Total Phenolic Content), TFC (Total Flavonoids Content), TTC (Total Condensed Tannins Content), TSC (Total Sugars Content), and the antioxidant activity by DPPH and ABTS assays of Opuntia ficus Indica seeds. The correlation between the bioactive molecules and their antioxidant capabilities is evaluated by the Principal Component Analysis (PCA). A Hierarchical Cluster Analysis (HCA) was used to construct three clusters based on their bioactive compounds and antioxidant capacities.

\section{Materials and Methods}

\subsection{Vegetals materials sites.}

The plant seeds from Opuntia ficus Indica were harvested in the summer in the period between July and September 2019 in the Taza city region located in the East-North of Morocco.

\subsection{Preparation of experimental extracts and extraction of antioxidant compounds.}

After the material vegetal is collected (seeds), the seeds were isolated using water and dried in the dark at room temperature for 72 hours. Afterward, they are placed in an aluminum paper and roasted in a forced hot-air convection oven at different temperatures $\left(60^{\circ} \mathrm{C}, 130^{\circ} \mathrm{C}\right.$, $200^{\circ} \mathrm{C}$ ) for various durations $(10,30,50 \mathrm{~min})$. The seeds were then crushed using a grinder. The resulting fine powder is stored at room temperature in an airtight container. Next, $50 \mathrm{~g}$ of fine 
powder was extracted with ethanol solvent distilling between $40^{\circ} \mathrm{C}$ and $60{ }^{\circ} \mathrm{C}$ in a soxhlet. The solvent was evaporated by a rotary evaporator. The extract was stored at a temperature of about $4{ }^{\circ} \mathrm{C}$ for subsequent analysis.

\subsection{Chemicals and reagents.}

The chemical reagents used in this work are classified as follows: 2,2'-azino-bis (3ethyl benzthiazoline-6-sulphonic acid), 2, 2-diphenyl-1-pycridazil (DPPH .90\%), Ascorbic acid, aluminum chloride ( $\mathrm{ALCL}_{3}$ ), 2-thiobarbituric acid (TBA), $\mathrm{KH}_{2} \mathrm{PO}_{4}, \mathrm{~K}_{2} \mathrm{HPO}_{4}$, sulfuric acid, potassium persulphate, phenol, ethylene-diamine, tetraacetic acid, Folin-Ciocalteau's phenol reagent, sodium carbonate, sodium acetate, aluminum chloride, sodium hydroxide, ethanol, methanol, ferrous sulfate, ferric chloride, and 2,4,6-Tris (1-pyridyl )-5-traizine (TPTZ).

\subsection{Total phenolic content (TPC).}

The polyphenol content was done by the assay of Singleton et al. 1999[17], $200 \mu$ l gent of seeds extracts was added to $1.5 \mathrm{ml}$ of Folin-Ciocalteu reagent (10\% diluted). After about 4 minutes of dilution, $1.5 \mathrm{ml}$ of $5 \%$ sodium carbonate $\left(\mathrm{Na}_{2} \mathrm{CO}_{3}\right)$ was added to the mixture and left in darkness. The results were collected after 2 hours by a spectrophotometer at $750 \mathrm{~nm}$. The concentration of TPC was obtained according to a calibration interval using Galic Acid (0$100 \mu \mathrm{g} / \mathrm{ml}$ ). The concentration of total polyphenols is expressed milligrams equivalent of a Gallic Acid gram of extract (mg EGA / g extract).

\subsection{Total flavonoids content (TFC).}

The aluminum trichloride ( $\mathrm{AlCl}_{3}$ ) assay described byYeddes et al., 2013[18], is used to quantify the flavonoids in our extracts. One $\mathrm{mL}$ of each sample diluted is mixed with one $\mathrm{ml}$ of a solution of Aluminum chloride $\left(\mathrm{AlCl}_{3}\right)$ diluted to $2 \%$ in methanol. Consequently, the absorbance was measured at $430 \mathrm{~nm}$ after 10 minutes of the start of the reaction. Quercetin was used to establish a calibration curve. Therefore, the TFC was expressed in milligrams equivalent of quercetin per gram of extract (mg EQ / g extract).

\subsection{Total condensed tannins content (TTC).}

The analysis of TTC was obtained by Sun et al., 1998 [19]. $50 \mathrm{ml}$ of diluted extract (50$600 \mu \mathrm{g} / \mathrm{mL}$ ), $3 \mathrm{~mL}$ of $4 \%$ vanillin solution in methanol, and 1.5 of concentrated $\mathrm{H}_{2} \mathrm{SO}_{4}$ were added. The mixture was allowed to stand for $15 \mathrm{~min}$, and the absorbance was measured at 430 $\mathrm{nm}$, using catechin to establish a calibration curve. The TTC was expressed in mg catechin equivalent $(\mathrm{CE})$ per gram of extract.

\subsection{Total sugars content (TSC).}

The TSC of Opuntia ficus Indica seeds extract was determined by Chaiwut et al. [20]. We used the phenol-sulfuric acid method. One $\mathrm{mL}$ of each extract was added to $1 \mathrm{~mL}$ of aqueous phenol $5 \%$. Then $5 \mathrm{~mL}$ of sulphuric acid was added to the mixture. After that, the mixture was incubated at $50^{\circ} \mathrm{C}$ for $20 \mathrm{~min}$. The absorbance was read at $490 \mathrm{~nm}$. The TTC was determined by a linear regression equation established using glucose. Therefore, the TSC was expressed in milligrams equivalent of glucose per gram of extract (mg D-GluE/ g extract). 


\subsection{Radical scavenging activity of DPPH (1-diphenyl picrylhydrazyl).}

The free radical removal activity of the extracts was carried out using the method of Zengin et al. 2015 [21] with slight modification. A stable free radical, DPPH, was used. 1mL of each sample at different concentrations $(50$ to $1000 \mu \mathrm{g} / \mathrm{mL}$ ) was added to $1 \mathrm{~mL}$ of DPPH methanol solution at $0.1 \mathrm{mM}$ and left to stand for $30 \mathrm{~min}$ at $27^{\circ} \mathrm{C}$. Both DPPH and methanol were used as controls. The mixture was incubated at $37^{\circ} \mathrm{C}$ in the dark for $20 \mathrm{~min}$; after that, the absorbance was collected at $517 \mathrm{~nm}$. The antiradical activity was estimated according to the following equation: \% Radical scavenging activity DPPH $=1$-[A sample / A control] x 100, where A sample and A control are the absorbances of the sample and the control.

\subsection{Radical cation inhibition activity (ABTS).}

The radical cation activity of Opuntia ficus Indica extracts was estimated according to the method of Yim et al., 2013[22]. $88 \mu \mathrm{L}$ of $140 \mathrm{mM}$ of potassium persulfate $\left(\mathrm{K}_{2} \mathrm{~S}_{2} \mathrm{O}_{8}\right)$ was mixed with $5 \mathrm{~mL}$ of $7 \mathrm{mM} \mathrm{ABTS}^{+}$solution. The solution was stored in the dark for $16 \mathrm{~h}$ at room temperature. Then, the absorbance of the solution was adjusted using ethanol to $0.70 \pm 0.05$ at $734 \mathrm{~nm} .10 \mu \mathrm{L}$ of Opuntia ficus Indica extract at different concentrations was added to one $\mathrm{mL}$ of $\mathrm{ABTS}^{++}$solution $(100$ to $1000 \mu \mathrm{g} / \mathrm{mL})$. The absorbance was measured against the blank reagent at $734 \mathrm{~nm}$. The inhibition activity was determined by the following equation: \% Radical inhibition activity ABTS $=1$-[A sample / A control] x 100 where A sample and A control were the absorbances of the sample and the control.

\subsection{Preparation of extracts according to the experimental design.}

In this work, we used Box-Behnken Design(BBD); this technique consists of 15 experimental assays (Table 2). It was used for the optimization of roasting conditions and extraction factors. Three factors (independent variables) were optimized, which are roasting temperature, roasting time, and extraction time. These factors had 3 levels $(-1,0,+1)$, which are lower, medium, and higher, respectively. Table 1 presents the domains of variation and the coded levels of the three variables. TPC, TTC, TFC, TSC, and the antioxidant capacity by ABTS and DPPH assays were selected as the responses of model design (Y) of this work, and they are mentioned in Table 2.

Table 1. Levels of the roasting factors by BBD.

\begin{tabular}{l|l|c|c|c} 
Extraction Process & Independent Variables & \multicolumn{3}{c}{ Level } \\
\cline { 3 - 5 } & & $(-1)$ & $(0)$ & $(+1)$ \\
\hline \multirow{2}{*}{ soxhlet process } & $\mathrm{X}_{1}$ roastingtemperature $\left({ }^{\circ} \mathrm{C}\right)$ & 60 & 130 & 200 \\
\cline { 2 - 5 } & $\mathrm{X}_{2}$ roasting time $(\mathrm{min})$ & 10 & 30 & 50 \\
\cline { 2 - 5 } & $\mathrm{X}_{3}$ extraction time $(\mathrm{h})$ & 3 & 4.5 & 6
\end{tabular}

The regression coefficients $(\beta)$ were generated by the adjustment of the experimental results to a second-order polynomial model. The second-order polynomial model for response surface analysis was presented as follows [23]:

$\mathrm{Y}=\beta_{0}+\sum \beta_{i} X_{i}+\sum \beta_{i i} X_{i}^{2}+\sum \beta_{i j} X_{i} X_{j}(1)$

Where $\mathrm{Y}$ is the predicted response, as well as $\mathrm{X}_{\mathrm{i}}$ and $\mathrm{X}_{\mathrm{j}}$ were the independent variables. Moreover, $\beta 0, \beta \mathrm{i}, \beta \mathrm{ii}$, and $\beta \mathrm{ij}$ was the regression coefficient of the mode (constant, linear, quadratic, and interactive effect), respectively. Furthermore, the analysis of variance (ANOVA) was used to obtain these regression coefficients using JMP11(SW) software. P- 
value of the model, a p-value of lack of fit, coefficient of determination $\left(\mathrm{R}^{2}\right)$, and coefficient of adjustment $\left(\mathrm{R}^{2}\right.$ adj) were used to estimate the adequacy of the polynomial equation of the response. The desirability function was used for multi-response prediction [24]. The significance of all terms of the models was considered statistically different when the p-value $<0.05$. The surface graphs (3D) were visualized by JMP 11 (SW ) software [25].

2.11. Principal component analysis (PCA), hierarchical cluster analysis (HCA), and matrix correlation.

The Pearson correlations between TPC, TFC, TTC, TSC, DPPH, and ABTS were performed by PCA, which represented the 15 samples according to their response values graphically in order to enable visual correlation of the data depending on the nature of the roasting condition and extraction time. HCA was performed to pursue the interrelatedness between all extracts into clusters on the basis of measured bioactive compounds characteristics. Moreover, the similarities between the analyzed extracts are represented in the form of dendrograms generated by the XLSTAT 2014 software. The distances between extracts were calculated using square Euclidean distances. This technique uses an analysis of variance approach to evaluate the distances between clusters [26].

\subsection{Data analysis.}

Box-Behnken Design (BDD) was applied in order to optimize the roasting factors and extraction time for extracts from Opuntia ficus Indica seeds using JMP 11 (SW) software. Moreover, PCA, HCA, and Pearson correlations were performed using XLSTAT 2014 software[27,28]. The IBM SPSS Statistics 21 software was used to present the results in means \pm standard error of the mean. The significance of the results used by the Tukey test at alpha $=0.05$.

\section{Results and Discussion}

Optimization of roasting conditions and extraction time was carried out in 15 randomized trials. Table 2shows the data collected for TFC, TPC, TTC, TSC, ABTS ( IC50), and DPPH ( $\left.\mathrm{IC}_{50}\right)$ of extracts seeds from Opuntia ficus Indica from Morocco.

3.1. Second-order polynomial model and interpretation of the response surface model of TPC and TFC.

The TPC and TFCof extract seeds from Opuntia ficus Indica varied from 31.14 \pm 0.90 to $103.76 \pm 1.82 \mathrm{mg} \mathrm{GAE} / \mathrm{g}$ extract and $26.14 \pm 0.98$ to $\mathrm{mgQE} / \mathrm{g}$ extract, respectively. According to data from ANOVA for TPC and TFC (Table 3), the models were significant; their $\mathrm{p}$-value is $<0.0001$ and $<0.0015$, respectively. The coefficient of determination $\left(\mathrm{R}^{2}\right)$ was 0.996167 and 0.976653 for TPC and TFC, respectively; these values indicated that the models are adequate because $\mathrm{R}^{2}$ was more than $0.75[29]$.

Table 2. Results of TFC, TPC, TTC, TSC, ABTS (IC $\left.\mathrm{C}_{50}\right)$, and DPPH ( $\left.\mathrm{IC}_{50}\right)$ according to experimental design.

\begin{tabular}{c|l|l|l|l|l|l|l|l|l} 
Run & $\mathbf{X}_{\mathbf{1}}$ & $\mathbf{X}_{\mathbf{2}}$ & $\mathbf{X}_{\mathbf{3}}$ & \multicolumn{1}{|c}{ TPC } & \multicolumn{1}{|c}{ TFC } & \multicolumn{1}{|c}{ TTC } & TSC & DPPHIC $_{\mathbf{5 0}}$ & ABTS IC $_{\mathbf{5 0}}$ \\
\hline $\mathbf{1}$ & 200 & 10 & 4.5 & $76.43 \pm 0.90^{\mathrm{a}}$ & $83.286 \pm 0.802^{\mathrm{a}}$ & $6.05 \pm 0.95^{\mathrm{ad}}$ & $40.32 \pm 0.91^{\text {ah }}$ & $205.35 \pm 1.21^{\mathrm{a}}$ & $711.89 \pm 2.1^{\mathrm{a}}$ \\
\hline $\mathbf{2}$ & 60 & 50 & 4.5 & $44.51 \pm 1.29^{\mathrm{b}}$ & $38.45 \pm 0.71^{\mathrm{b}}$ & $1.23 \pm 0.20^{\mathrm{b}}$ & $39.56 \pm 0.79^{\mathrm{a}}$ & $321.43 \pm 1.29^{\mathrm{b}}$ & $950.64 \pm 1.19^{\mathrm{b}}$ \\
\hline $\mathbf{3}$ & 60 & 30 & 3 & $34.86 \pm 1.12^{\mathrm{cf}}$ & $30.14 \pm 0.86^{\mathrm{cg}}$ & $1.61 \pm 0.29^{\mathrm{b}}$ & $29.02 \pm 0.98^{\mathrm{be}}$ & $430.67 \pm 1.19^{\mathrm{c}}$ & $1090.15 \pm 1.95^{\mathrm{c}}$ \\
\hline $\mathbf{4}$ & 130 & 50 & 6 & $66.58 \pm 1.19^{\mathrm{d}}$ & $48.54 \pm 1.40^{\mathrm{d}}$ & $6.83 \pm 0.41^{\mathrm{ac}}$ & $23.37 \pm 0.82^{\mathrm{c}}$ & $210.26 \pm 1.08^{\mathrm{a}}$ & $620.36 \pm 1.31^{\mathrm{d}}$ \\
\hline $\mathbf{5}$ & 130 & 30 & 4.5 & $56.46 \pm 0.80^{\mathrm{e}}$ & $44.03 \pm 0.97^{\mathrm{bd}}$ & $3.25 \pm 0.20^{\text {be }}$ & $30.17 \pm 0.93^{\text {be }}$ & $230.64 \pm 0.83^{\mathrm{d}}$ & $684.23 \pm 1.11^{\mathrm{e}}$ \\
\hline
\end{tabular}


https://doi.org/10.33263/BRIAC113.1051010532

\begin{tabular}{|c|c|c|c|c|c|c|c|c|c|}
\hline Run & $\mathbf{X}_{1}$ & $\mathbf{X}_{2}$ & $\mathbf{X}_{3}$ & TPC & TFC & TTC & TSC & DPPHIC $_{50}$ & ABTS IC 50 \\
\hline 6 & 60 & 30 & 6 & $39.29 \pm 0.81^{\text {bf }}$ & $43.38 \pm 1.30^{\mathrm{bd}}$ & $1.41 \pm 0.31^{\mathrm{b}}$ & $26.36 \pm 0.31^{\mathrm{bc}}$ & $390.92 \pm 1.98^{\mathrm{e}}$ & $1010.76 \pm 2.90^{f}$ \\
\hline 7 & 200 & 30 & 6 & $90.71 \pm 1.10^{\mathrm{g}}$ & $72.57 \pm 0.93^{\mathrm{e}}$ & $7.76 \pm 0.79^{\mathrm{ac}}$ & $10.35 \pm 0.32^{\mathrm{d}}$ & $120.17 \pm 2.10^{\mathrm{f}}$ & $445.48 \pm 0.91^{\mathrm{g}}$ \\
\hline 8 & 130 & 10 & 6 & $35.38 \pm 0.89^{\mathrm{cf}}$ & $35.16 \pm 1.06^{\mathrm{igj}}$ & $2.16 \pm 0.20^{\mathrm{b}}$ & $27.93 \pm 0.97^{\text {be }}$ & $350.39 \pm 0.65^{\mathrm{g}}$ & $914.91 \pm 1.99^{\mathrm{h}}$ \\
\hline 9 & 130 & 50 & 3 & $52.91 \pm 1.01^{\mathrm{e}}$ & $39.54 \pm 1.29^{\mathrm{bj}}$ & $3.12 \pm 0.18^{\text {be }}$ & $26.03 \pm 0.98^{\mathrm{bc}}$ & $251.18 \pm 2.02^{\mathrm{h}}$ & $736.93 \pm 1.03^{\mathrm{i}}$ \\
\hline 10 & 130 & 30 & 4.5 & $57.57 \pm 1.28^{\mathrm{e}}$ & $46.97 \pm 0.98^{\mathrm{d}}$ & $3.67 \pm 0.33^{\mathrm{dbe}}$ & $31.26 \pm 0.68^{\mathrm{eg}}$ & $231.53 \pm 1.19^{d}$ & $682.01 \pm 1.01^{\mathrm{e}}$ \\
\hline 11 & 200 & 50 & 4.5 & $103.76 \pm 1.82^{\mathrm{h}}$ & $106.71 \pm 1.20^{\mathrm{f}}$ & $9.12 \pm 0.90^{c}$ & $15.54 \pm 0.39^{f}$ & $76.91 \pm 0.99^{i}$ & $323.52 \pm 1.21^{\mathrm{j}}$ \\
\hline 12 & 60 & 10 & 4.5 & $28.26 \pm 1.09^{\mathrm{i}}$ & $28.34 \pm 0.96^{\mathrm{c}}$ & $1.54 \pm 0.30^{\mathrm{b}}$ & $34.91 \pm 0.99^{\mathrm{g}}$ & $491.27 \pm 2.11^{\mathrm{j}}$ & $1157.36 \pm 2.11^{\mathrm{k}}$ \\
\hline 13 & 200 & 30 & 3 & $80.07 \pm 0.98^{\mathrm{a}}$ & $98.86 \pm 1.10^{\mathrm{h}}$ & $5.31 \pm 0.70^{\mathrm{ae}}$ & $34.02 \pm 0.61^{\mathrm{g}}$ & $171.73 \pm 1.09^{\mathrm{k}}$ & $610.32 \pm 2.69^{1}$ \\
\hline 14 & 130 & 10 & 3 & $31.14 \pm 0.90^{\mathrm{ci}}$ & $26.14 \pm 0.98^{c}$ & $1.76 \pm 0.18^{\mathrm{b}}$ & $44.62 \pm 0.79^{\mathrm{h}}$ & $412.67 \pm 2.20^{1}$ & $1054.52 \pm 2.21^{\mathrm{m}}$ \\
\hline 15 & 130 & 30 & 4.5 & $56.03 \pm 1.01^{\mathrm{e}}$ & $43.24 \pm 0.86^{\mathrm{bd}}$ & $3.41 \pm 0.30^{\mathrm{dbe}}$ & $29.46 \pm 0.48^{\text {be }}$ & $232.06 \pm 0.98^{\mathrm{d}}$ & $681.09 \pm 1.02^{\mathrm{e}}$ \\
\hline \multicolumn{10}{|c|}{$\begin{array}{l}\text { The results are expressed in the form of an average of } 2 \text { individual repetitions }(\mathrm{n}=2 \mathrm{e} \pm \mathrm{SEM}) \text {. The mean followed by similar letters } \\
\text { exposing in the column are not different }(\mathrm{P}<0.05) \text {. TPC }(\mathrm{mg} \text { GAE } / \mathrm{g} \text { extract }): \mathrm{TFC}(\mathrm{mg} \text { QE } / \mathrm{g} \text { extract }): \text { TTC }(\mathrm{mg} \text { QAE} / \mathrm{g} \text { extract) } \\
\text { TSC }(\mathrm{mg} \text { D-Glu E/g extract }) ; \mathrm{DPPHIC} 50(\mu \mathrm{g} / \mathrm{ml}): \text { ABTS IC50 }(\mu \mathrm{g} / \mathrm{ml}) ; \mathrm{X}_{1} \text { :roasting temperature }\left({ }^{\circ} \mathrm{C}\right) ; \mathrm{X}_{2} \text { : roasting time (min); } \\
\text { X3:extraction time (h). }\end{array}$} \\
\hline
\end{tabular}

Additionally, the adjusted determination coefficient $\mathrm{R}_{\mathrm{adj}}{ }^{2}$ was 0.989267 and 0.934629 for the TPC and TFC; respectively, this indicates that the models adequately presented the true combination between all independents variables used. Moreover, the lack of fit was not significant for TPC and TFC because their p-values were 0.0673 and 0.0536 , respectively, which indicated that the model equations were adequate for predicting the response values. Equations (2) and (3) can predict the effect of independent variables on the content of TPC and TFC, respectively. They were represented by a reduced regression model.

$\mathrm{TPC}(\mathrm{mgGAE} /$ gextract $)=56.686667+25.50625 \mathrm{X}_{1}+12.06875 \mathrm{X}_{2}+4.1225 \mathrm{X}_{3}+2.77 \mathrm{X}_{1} * \mathrm{X}_{2}+1.5525 \mathrm{X}_{1}$ $\mathrm{X}_{3}+2.3575 \mathrm{X}_{2} * \mathrm{X}_{3}+10.641667 \mathrm{X}_{1} * \mathrm{X}_{1}-4.088333 \mathrm{X}_{2} * \mathrm{X}_{2}-6.095833 \mathrm{X}_{3} * \mathrm{X}_{3}$

TFC $(\mathrm{mg}$ QE/g extract $)=44.746667+27.6395 \mathrm{X}_{1}+7.53925 \mathrm{X}_{2}+0.62125 \mathrm{X}_{3}+3.3285 \mathrm{X}_{1} * \mathrm{X}_{2}-9.8825 \mathrm{X}_{1} *$ $\mathrm{X}_{3}-0.005 \mathrm{X}_{2} * \mathrm{X}_{3}+21.671167 \mathrm{X}_{1} * \mathrm{X}_{1}-2.221333 \mathrm{X}_{2} * \mathrm{X}_{2}-5.180333 \mathrm{X}_{3} * \mathrm{X}_{3}$

The data of ANOVA for TPC (Table 2) showed that the factors $\mathrm{X}_{1}, \mathrm{X}_{2}$, and $\mathrm{X}_{3}$ had a significant positive linear effect on TPC since their $\mathrm{p}$-values were $<0.0001,<0.0001$, and 0.0043 , respectively. Also, the quadratic effect $\mathrm{X}_{1} * \mathrm{X}_{1}$ had a significant positive effect ( $\mathrm{p}$ value $=0.0003$ ). On the contrary, the quadratic effects $\mathrm{X}_{2} * \mathrm{X}_{2}$ and $\mathrm{X}_{3} * \mathrm{X}_{3}$ had a significant negative effect on TPC ( $\mathrm{p}$-value $<0.05$ ). Furthermore, no significant interaction between the three factors tested was observed (Table 2).

Table 3. Data on the ANOVA of the regression coefficient and the terms of the model.

\begin{tabular}{|c|c|c|c|c|c|c|}
\hline Source & Coef & $\begin{array}{l}\text { Sum of } \\
\text { square }\end{array}$ & $\begin{array}{l}\text { Degree of } \\
\text { freedom }\end{array}$ & Mean square & F-avlue & p-avlue \\
\hline \multicolumn{7}{|l|}{ TPC } \\
\hline Model & & 7236.7311 & 9 & 804.081 & 144.3821 & $<0.0001^{*}$ \\
\hline Constant & 56.686667 & & & & & $<0.0001 *$ \\
\hline $\mathrm{X}_{1}$ & 25.50625 & 5204.5503 & 1 & 5204.5503 & 934.5376 & $<0.0001^{*}$ \\
\hline$X_{2}$ & 12.06875 & 1165.2378 & 1 & 1165.2378 & 209.2320 & $0.0001 *$ \\
\hline $\mathrm{X}_{3}$ & 4.1225 & 135.9601 & 1 & 135.9601 & 24.4132 & $0.0043^{*}$ \\
\hline $\mathrm{X}_{1} * \mathrm{X}_{2}$ & 2.77 & 30.6916 & 1 & 30.6916 & 5.5110 & 0.0658 \\
\hline $\mathrm{X}_{1} * \mathrm{X}_{3}$ & 1.5525 & 9.6410 & 1 & 9.6410 & 1.7312 & 0.2454 \\
\hline $\mathrm{X}_{2} * \mathrm{X}_{3}$ & 2.3575 & 22.2312 & 1 & 22.2312 & 3.9919 & 0.1022 \\
\hline $\mathrm{X}_{1} * \mathrm{X}_{1}$ & 10.641667 & 418.1356 & 1 & 418.1356 & 75.0811 & $0.0003^{*}$ \\
\hline $\mathrm{X}_{2} * \mathrm{X}_{2}$ & -4.088333 & 61.7150 & 1 & 61.7150 & 11.0816 & $0.0208^{*}$ \\
\hline $\mathrm{X}_{3} * \mathrm{X}_{3}$ & -6.095833 & 137.2031 & 1 & 137.2031 & 24.6364 & $0.0042 *$ \\
\hline Residual & & 27.8456 & 5 & 5.569 & & \\
\hline Total & & 7264.5767 & 14 & & & \\
\hline Lack of fit & & 26.582725 & 3 & 8.86091 & 14.0330 & 0.0673 \\
\hline Pure Error & & 1.262867 & 2 & 0.63143 & & \\
\hline Total Error & & 27.845592 & 5 & & & \\
\hline $\mathrm{R}^{2}$ & 0.996167 & & & & & \\
\hline $\operatorname{Radj}^{2}$ & 0.989267 & & & & & \\
\hline TFC & & & & & & \\
\hline
\end{tabular}




\begin{tabular}{l|l|l|l|l|l|l}
\hline Source & Coef & $\begin{array}{l}\text { Sum of } \\
\text { square }\end{array}$ & $\begin{array}{l}\text { Degree of } \\
\text { freedom }\end{array}$ & Mean square & F-avlue & p-avlue \\
\hline Model & & 8955.6569 & 9 & 995.073 & 23.2404 & $0.0015^{*}$ \\
\hline Constant & 44.746667 & & & & & $<0.0001^{*}$ \\
\hline $\mathrm{X}_{1}$ & 27.6395 & 6111.5357 & 1 & 6111.5357 & 142.7375 & $<0.0001^{*}$ \\
\hline $\mathrm{X}_{2}$ & 7.53925 & 454.7223 & 1 & 454.7223 & 10.6202 & $0.0225^{*}$ \\
\hline $\mathrm{X}_{3}$ & 0.62125 & 3.0876 & 1 & 3.0876 & 0.0721 & 0.7990 \\
\hline $\mathrm{X}_{1} * \mathrm{X}_{2}$ & 3.3285 & 44.3156 & 1 & 44.3156 & 1.0350 & 0.3557 \\
\hline $\mathrm{X}_{1} * \mathrm{X}_{3}$ & -9.8825 & 390.6552 & 1 & 390.6552 & 9.1239 & $0.0294^{*}$ \\
\hline $\mathrm{X}_{2} * \mathrm{X}_{3}$ & -0.005 & 0.0001 & 1 & 0.0001 & 0.0000 & 0.9988 \\
\hline $\mathrm{X}_{1} * \mathrm{X}_{1}$ & 21.671167 & 1734.0534 & 1 & 1734.0534 & 40.4996 & $0.0014^{*}$ \\
\hline $\mathrm{X}_{2} * \mathrm{X}_{2}$ & -2.221333 & 18.2190 & 1 & 18.2190 & 0.4255 & 0.5430 \\
\hline $\mathrm{X}_{3} * \mathrm{X}_{3}$ & -5.180333 & 99.0862 & 1 & 99.0862 & 2.3142 & 0.1887 \\
\hline Residual & & 214.0830 & 5 & 42.817 & & \\
\hline Total & & 9169.7398 & 14 & & & \\
\hline Lack of fit & & 206.35613 & 3 & 68.7854 & 17.8042 & 0.0536 \\
\hline Pure Error & & 7.72687 & 2 & 3.8634 & & \\
\hline Total Error & & 214.08300 & 5 & & & \\
\hline $\mathrm{R}^{2}$ & 0.976653 & & & & & \\
\hline Radj & 0.934629 & & & & &
\end{tabular}

* Significant at p-value $<0.05$

Concerning the results of ANOVA for TFC, the roasting temperature $\left(\mathrm{X}_{1}\right)$ and roasting time $\left(\mathrm{X}_{2}\right)$ had a positive linear effect on TFC ( $\mathrm{p}$-value $\left.<0.05\right)$. However, the extraction time $\left(\mathrm{X}_{3}\right)$ was not significant ( $\mathrm{p}$-value>0.05). In addition ,the interaction effect between $\mathrm{X}_{1}$ and $\mathrm{X}_{3}$ had a significant negative effect on TFC ( $\mathrm{p}$-value>0.05). Furthermore, the quadratic effect of roasting temperature $\left(\mathrm{X}_{1}\right)$ had a significant negative effect on TFC ( $\mathrm{p}$-value $\left.=0.0014\right)$.

\subsection{Response surface methodology(RSM) analysis.}

The effects of three factors: roasting temperature, roasting time, and extraction time, as well as their interaction and quadratic effect on TPC and TFC were visualized on response surface (3D) plots shown in Figure1. Accordingly, Figure 1a shows TPC as a function of roasting temperature $(\mathrm{X} 1)$ and roasting time $(\mathrm{X} 2)$ at fixed extraction time $\left(\mathrm{X}_{3}\right)(6 \mathrm{~h})$. It showed that TPC rapidly increased when the roasting temperature $\left(\mathrm{X}_{1}\right)$ increased at a roasting time $\left(\mathrm{X}_{2}\right)$ fixed, as well as it increased gradually when the roasting time $\left(\mathrm{X}_{2}\right)$ increased and reached an optimum in the region close to $200^{\circ} \mathrm{C}$ and50min. Figure $1 \mathrm{~b}$ shows the effect of roasting time $\left(\mathrm{X}_{2}\right)$ and extraction time $\left(\mathrm{X}_{3}\right)$ at fixed roasting temperature $\left(200^{\circ} \mathrm{C}\right)$ on the TPC; the TPC increased with increasing extraction time $\left(\mathrm{X}_{3}\right)$ when the roasting time $\left(\mathrm{X}_{2}\right)$ was fixed, as well as, it increased gradually when the extraction time increased before passing $5 \mathrm{~h}$ of extraction, after that, it decreased. The effect of roasting temperature $\left(\mathrm{X}_{1}\right)$ and extraction time $\left(\mathrm{X}_{3}\right)$ at a fixed roasting time $\left(\mathrm{X}_{2}\right)\left(50^{\circ} \mathrm{C}\right)$ is shown in Figure 1c; accordingly, TFC increased with increasing roasting time when the extraction time was fixed. Also, when the roasting temperature was fixed, the TFC increased before the extraction time increased at 5h; after that, it decreased marginally. Moreover, the optimization of the response values was carried out according to desirability function (d) in order to achieve the optimal response for TPC, for instance. The optimum response for TPC was found when the desirability was close to 1 (Figure 4) $[24,30,31]$. Therefore, the optimum of TPC was at roasting temperature $200{ }^{\circ} \mathrm{C}$, roasting time $50 \mathrm{~min}$, and extraction time $5.49 \mathrm{~h}$ with $106.2311 \mathrm{mg} \mathrm{GAE} / \mathrm{g}$ extract predicted response and desirability $d=0.94$ (Figure. $4 \mathrm{a}$ ). These results were consistent with the previous studies of TPC. Chandrasekara and Shahidi,2011[32] indicated that the roasting at high temperatures $\left(130^{\circ} \mathrm{C}\right)$ for 33 min increased the TPC significantly more than the raw seeds (testa, cashew nuts). Also, the TPC (in both water and ethanol) from peanut skin increased by about35\% relative to the raw sample at a roasting temperature of $175{ }^{\circ} \mathrm{C}$ for $5 \min [33]$. Moreover, in the study done by 
Locatelli et al. [34], the TPC of hazelnut skin(extract soluble ) increased at $180^{\circ} \mathrm{C}$ for $20 \mathrm{~min}$ more than $10 \mathrm{~min}$. In addition, Yin et al. [35] showed that the TPC increased about 2.4-3.4 times at a temperature between $120^{\circ} \mathrm{C}$ and $140^{\circ} \mathrm{C}$ for $180 \mathrm{~min}$. Moreover, the TPC significantly increased (p-value $<0.05$ ) at a heat treatment [36].

Concerning the TFC, Figure 1d shows the response surface plot of roasting temperature $\left(\mathrm{X}_{1}\right)$ and roasting time $\left(\mathrm{X}_{2}\right)$ on the total flavonoids content when the extraction time $\left(\mathrm{X}_{3}\right)$ was fixed at $3 \mathrm{~h}$. The TFC was stable when the roasting time was fixed, and the roasting temperature increased between $60-120^{\circ} \mathrm{C}$; beyond $120^{\circ} \mathrm{C}$, the TFC quickly increased. Also, the TFC slightly increased with increasing roasting time $\left(\mathrm{X}_{2}\right)$ when the roasting temperature was fixed. In addition, Figure 1e showed that the effect of roasting time $\left(\mathrm{X}_{2}\right)$ and extraction time $\left(\mathrm{X}_{3}\right)$ on the TFC when the roasting temperature was fixed at $200^{\circ} \mathrm{C}$; the TFC increased with the increasing of the roasting time $\left(\mathrm{X}_{2}\right)$ when the extraction time fixed, but, it decreased with the increasing of the extraction time $\left(\mathrm{X}_{3}\right)$ when the roasting time $\left(\mathrm{X}_{2}\right)$ fixed.
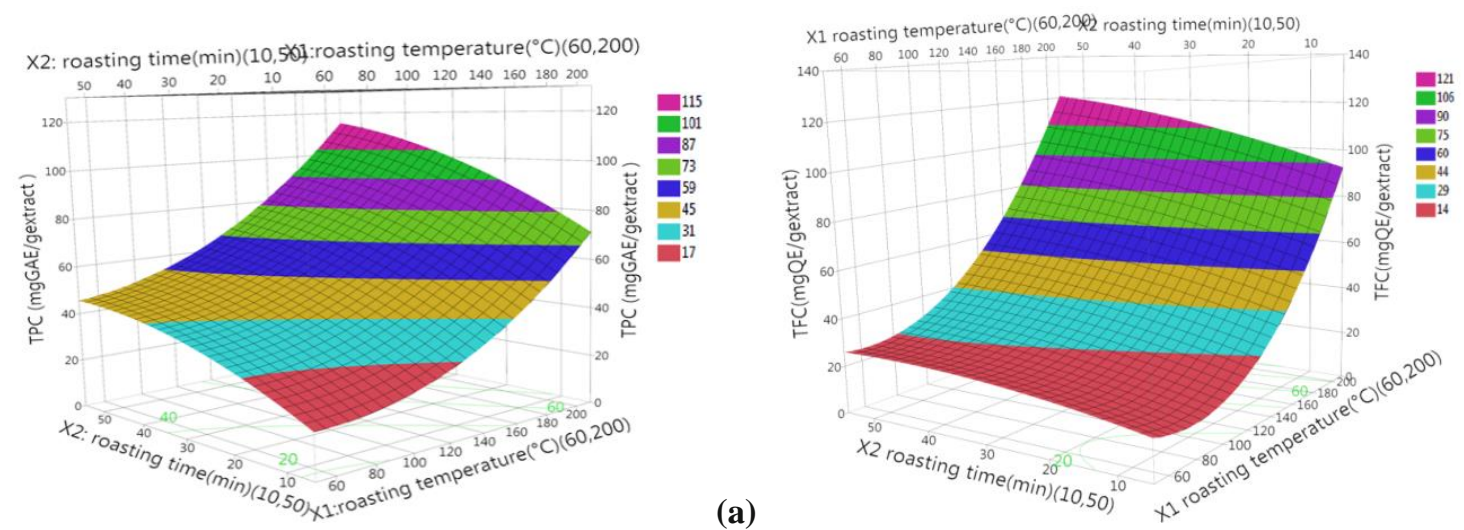

(d)


(e)
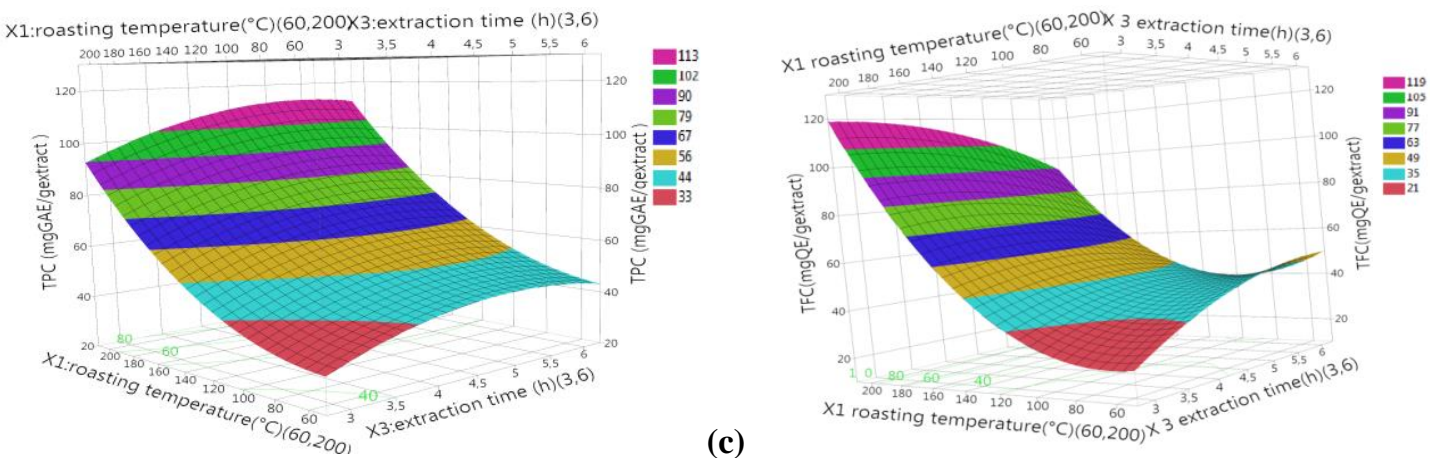

(f)

Figure 1. Response surface plots of roasting conditions of TPC (a, b, and c) and TFC (d, e, and f) of the Opuntia ficus Indica seeds extracts.

Moreover, the effect of the roasting temperature $\left(\mathrm{X}_{1}\right)$ and extraction time $\left(\mathrm{X}_{3}\right)$ on the TFC when the roasting time $\left(\mathrm{X}_{2}\right)$ was fixed at $50^{\circ} \mathrm{C}$ (Figure1f), according to that, the TFC 
slightly increased with the increasing of extraction time when the $\mathrm{X}_{1}$ fixed. Also, the TFC quickly increased with the increasing of roasting temperature when the $\mathrm{X} 3$ was fixed. The strong level of TFC was recorded at a higher roasting temperature. Consequently, the maximum of TFC was at roasting temperature $200{ }^{\circ} \mathrm{C}$, roasting time $50 \mathrm{~min}$, and extraction time $3.16 \mathrm{~h}$ with $106.85 \mathrm{mgQE} / \mathrm{g}$ extract predicted response and the desirability is $\mathrm{d}=0.948$ (Figure $4 \mathrm{~b}$ ). These results are similar to various works. Lin et al. [37] indicated that the TFC increased significantly by roasting (after $5 \mathrm{~min}$ ); in addition to that, the flavonoid aglycones and acids are increased by the effects of roasting temperature and roasting time. Furthermore, a study was done by Kumar et al.[48] showed that the fraction of sugar in flavonoids glycosides had an essential role in antioxidant activity, and the aglycones had a strong effect on the antioxidant activity more than the glycosides. The results of TPC and TFC of this study after the roasting can be explained by these causes. First, the phenolic molecules can be degraded/polymerized during the roasting, which showed the formation of new molecules; these molecules can be more soluble in water and ethanol. Also, these molecules can be reagent with the FolinCiocalteu in the alkaline middle [33]. Secondly, during the roasting, the bound compounds bioactive can be released [39].

3.3. Second-order polynomial model and interpretation of the response surface model of TTC and TSC.

In this work, the TTC and TSC of extract seeds from Opuntia ficus Indica varied from $1.23 \pm 0.20$ to $9.12 \pm 0.90 \mathrm{mg}$ QAE/g extract and from $10.35 \pm 0.32$ to $44.62 \pm 0.79 \mathrm{mg}$ D-Glu E/g extract, respectively. According to data of ANOVA presented in Table 4, the models were significant because their p-value was 0.0023 and 0.0004 for TTC and TSC, respectively.

\begin{tabular}{|c|c|c|c|c|c|c|}
\hline Source & Coef & $\begin{array}{l}\text { Sum of } \\
\text { square }\end{array}$ & $\begin{array}{l}\text { Degree of } \\
\text { freedom }\end{array}$ & Mean square & F-value & p-value \\
\hline \multicolumn{7}{|l|}{ TTC } \\
\hline Model & & 87.863198 & 9 & 9.76258 & 19.1480 & $0.0023 *$ \\
\hline Constant & 3.4433333 & & & & & $0.0004 *$ \\
\hline $\mathrm{X}_{1}$ & 2.80625 & 63.000313 & 1 & 63.000313 & 123.5668 & $0.0001 *$ \\
\hline$X_{2}$ & 1.09875 & 9.658013 & 1 & 9.658013 & 18.9429 & $0.0073 *$ \\
\hline $\mathrm{X}_{3}$ & 0.795 & 5.056200 & 1 & 5.056200 & 9.9171 & $0.0254 *$ \\
\hline$X_{1} * X_{2}$ & 0.845 & 2.856100 & 1 & 2.856100 & 5.6019 & 0.0642 \\
\hline $\mathrm{X}_{1} * \mathrm{X}_{3}$ & 0.6625 & 1.755625 & 1 & 1.755625 & 3.4434 & 0.1227 \\
\hline $\mathrm{X}_{2} * \mathrm{X}_{3}$ & 0.8275 & 2.739025 & 1 & 2.739025 & 5.3722 & 0.0682 \\
\hline $\mathrm{X}_{1} * \mathrm{X}_{1}$ & 0.7983333 & 2.353241 & 1 & 2.353241 & 4.6156 & 0.0844 \\
\hline $\mathrm{X}_{2} * \mathrm{X}_{2}$ & 0.2433333 & 0.218626 & 1 & 0.218626 & 0.4288 & 0.5415 \\
\hline $\mathrm{X}_{3} * \mathrm{X}_{3}$ & -0.219167 & 0.177356 & 1 & 0.177356 & 0.3479 & 0.5810 \\
\hline Residual & & 2.549242 & 5 & 0.50985 & & \\
\hline Total & & 90.412440 & 14 & & & \\
\hline Lack of fit & & 2.4593750 & 3 & 0.819792 & 18.2446 & 0.0524 \\
\hline Pure Error & & 0.0898667 & 2 & 0.044933 & & \\
\hline Total Error & & 2.5492417 & 5 & & & \\
\hline $\mathrm{R}^{2}$ & 0.971804 & & & & & \\
\hline $\operatorname{Radj}^{2}$ & 0.921052 & & & & & \\
\hline \multicolumn{7}{|l|}{ TSC } \\
\hline Model & & 1107.8079 & 9 & 123.090 & 38.2405 & $0.0004 *$ \\
\hline Constant & 30.296667 & & & & & $<0.0001 *$ \\
\hline $\mathrm{X}_{1}$ & -3.7025 & 109.66805 & 1 & 109.66805 & 34.0707 & $0.0021 *$ \\
\hline $\mathrm{X}_{2}$ & -5.41 & 234.14480 & 1 & 234.14480 & 72.7421 & $0.0004 *$ \\
\hline $\mathrm{X}_{3}$ & -5.71 & 260.83280 & 1 & 260.83280 & 81.0333 & $0.0003 *$ \\
\hline $\mathrm{X}_{1} * \mathrm{X}_{2}$ & -7.3575 & 216.53123 & 1 & 216.53123 & 67.2701 & $0.0004 *$ \\
\hline $\mathrm{X}_{1} * \mathrm{X}_{3}$ & -5.2525 & 110.35503 & 1 & 110.35503 & 34.2842 & $0.0021 *$ \\
\hline$X_{2} * X_{3}$ & 3.5075 & 49.21022 & 1 & 49.21022 & 15.2882 & $0.0113^{*}$ \\
\hline $\mathrm{X}_{1} * \mathrm{X}_{1}$ & -1.632083 & 9.83519 & 1 & 9.83519 & 3.0555 & 0.1409 \\
\hline $\mathrm{X}_{2} * \mathrm{X}_{2}$ & 3.9179167 & 56.67719 & 1 & 56.67719 & 17.6080 & $0.0085^{*}$ \\
\hline
\end{tabular}




\begin{tabular}{l|l|l|l|l|l|l}
\hline Source & Coef & $\begin{array}{l}\text { Sum of } \\
\text { square }\end{array}$ & $\begin{array}{l}\text { Degree of } \\
\text { freedom }\end{array}$ & Mean square & F-value & p-value \\
\hline $\mathrm{X}_{3} * \mathrm{X}_{3}$ & -3.727083 & 51.29040 & 1 & 51.29040 & 15.9345 & $0.0104 *$ \\
\hline Residual & & 16.0942 & 5 & 3.219 & & \\
\hline Total & & 1123.9020 & 14 & & & \\
\hline Lack of fit & & 14.450100 & 3 & 4.81670 & 5.8595 & 0.1492 \\
\hline Pure Error & & 1.644067 & 2 & 0.82203 & & \\
\hline Total Error & & 16.094167 & 5 & & & \\
\hline $\mathrm{R}^{2}$ & 0.98568 & & & & & \\
\hline Radj $^{2}$ & 0.959904 & & & & &
\end{tabular}

Moreover, the lack of fit was not significant ( $\mathrm{p}$-value $>0.05$ ), which indicated that the models'equation was for $\mathrm{p}$ adequate for predicting the response values. In addition to that, the $\mathrm{R}^{2}$ values were 0.971804 and 0.98568 for TTC and TSC, respectively, which indicates that $97 \%$ of experimental results were compatibles [40]. These values showed that the models adequately presented the true combinations between all variables used. Furthermore, the adjusted determination coefficients $\mathrm{R}_{\mathrm{adj}}^{2}$ were 0.921052 and 0.959904 for TTC and TSC, respectively, which indicated that the models were adequate $\left(\mathrm{R}_{\mathrm{adj}}{ }^{2}>0.75\right)$ [29]. Consequently, the secondorder polynomial models were applied in equations 4 and 5 for TTC and TSC, respectively.

$\mathrm{TTC}(\mathrm{mgQAE} /$ gextract $)=3.4433333+2.80625 \mathrm{X}_{1}+1.09875 \mathrm{X}_{2}+0.795 \mathrm{X}_{3}+0.845 \mathrm{X}_{1} * \mathrm{X}_{2}+0.6625 \mathrm{X}_{1}$ $* \mathrm{X}_{3}+0.8275 \mathrm{X}_{2} * \mathrm{X}_{3}+0.7983333 \mathrm{X}_{1} * \mathrm{X}_{1}+0.2433333 \mathrm{X}_{2} * \mathrm{X}_{2}-0.219167 \mathrm{X}_{3} * \mathrm{X}_{3}(4)$

TSC $(\mathrm{mgD}-$ GluE/gextract $)=30.296667-3.7025 \mathrm{X}_{1}-5.41 \mathrm{X}_{2}-5.71 \mathrm{X}_{3}-7.3575 \mathrm{X}_{1} * \mathrm{X}_{2}-5.2525 \mathrm{X}_{1}$ $* \mathrm{X}_{3}+3.5075 \mathrm{X}_{2} * \mathrm{X}_{3}-1.632083 \mathrm{X}_{1} * \mathrm{X}_{1}+3.9179167 \mathrm{X}_{2} * \mathrm{X}_{2}-3.727083 \mathrm{X}_{3} * \mathrm{X}_{3}(5)$

According to Table 4 , the linear effect of roasting temperature $\left(\mathrm{X}_{1}\right)$, roasting time $\left(\mathrm{X}_{2}\right)$, and extraction time $\left(\mathrm{X}_{3}\right)$ had a significant positive effect on TTC (p-value $\left.<0.05\right)$. Moreover, the interaction effects between $\mathrm{X}_{1}, \mathrm{X}_{2}$, and $\mathrm{X}_{3}$ were not significant on TTC ( $\mathrm{p}$-value> 0.05). Also, the quadratic effect of three independent variables had no significance on TTC because their $\mathrm{p}$-value was $0.0844,0.5415$, and 0.5810 for $\mathrm{X}_{1}, \mathrm{X} 2$, and $\mathrm{X}_{3}$, respectively. As regards TSC, the linear effect of roasting temperature, roasting time, and extraction time had a significant negative effect ( $\mathrm{p}$-value $<0.05$ ). Additionally that, the interaction effects $\mathrm{X}_{1} * \mathrm{X}_{2}$ and $\mathrm{X}_{2} * \mathrm{X}_{3}$ had a significant negative effect on TSC ( $p$-value $>0.05$ ); on the contrary, the interaction effect between roasting time and extraction time had a significant positive effect on TSC because of its $p$-value is equal 0.0113. Furthermore, the quadratic effects $\mathrm{X}_{2} * \mathrm{X}_{2}$ had a significant positive effect on TSC ( $\mathrm{p}$-value $=0.0085$ ), but the quadratic effect of extraction time $\mathrm{X}_{3} * \mathrm{X}_{3}$ had a negative effect on TSC(p-value $=0.0104)$. On the contrary, the quadratic effect of $\mathrm{X}_{2} * \mathrm{X}_{2}$ was not significant ( $\mathrm{p}$-value $>0.05$ ).

\subsection{Response surface methodology (RSM) analysis.}

The responses surfaces (3D) of regression equations 4 and 5 were established by RSM to illustrate the effects of each independent variable studied on TTC and TSC (Figure 2). According to that, Figure $2 \mathrm{a}$ shows the influence of roasting temperature $\left(\mathrm{X}_{1}\right)$ and roasting time $\left(\mathrm{X}_{2}\right)$ on TTC when the extraction time $\left(\mathrm{X}_{3}\right)$ was fixed at $6 \mathrm{~h}$. It noted that the TTC increased with the increasing of the roasting temperature when the roasting time was fixed. Also, it is shown that the roasting time $\left(\mathrm{X}_{2}\right)$ had an influence on the TTC because the TTC slowly increased with the increase of $\mathrm{X}_{2}$ when the $\mathrm{X}_{1}$ was fixed. Moreover, the positive interaction effect $\mathrm{X}_{1} * \mathrm{X}_{2}$ on the TTC was observed. Figure $2 \mathrm{~b}$ shows the effect of roasting time and extraction time on the TTC when the $\mathrm{X}_{1}$ was fixed at $200^{\circ} \mathrm{C}$. Thus, the positive interaction $\mathrm{X}_{2}$ 
* $\mathrm{X}_{3}$ was recorded. Therefore, the TTC increased with the increase of the $\mathrm{X}_{2}$ and $\mathrm{X}_{1}$, respectively. Figure $2 \mathrm{c}$ showed the effect of roasting time and extraction time on the TTC when the roasting temperature was fixed at $50 \mathrm{~min}$. The positive effect of $\mathrm{X}_{2}$ and $\mathrm{X}_{3}$ on the TTC was observed. Therefore, the TTC increased with the increase of two factors $\mathrm{X}_{1}$ and $\mathrm{X}_{2}$. It reached a maximum of TTC in the region close to 50min and $6 \mathrm{~h}$. The maximum of TTC was at roasting temperature: $200{ }^{\circ} \mathrm{C}$, roasting time $50 \mathrm{~min}$, extraction time6h with $11.30 \mathrm{mg}$ QAE/g extract predicted responses, and the desirability is $d=0.99$ (Figure 4c). These results are agreed with those reported by Lin et al. [37]. They indicated that the ethanolic extracts had a strong level in the TTC during the roasting $\left(200^{\circ} \mathrm{C}\right.$ for $\left.20 \mathrm{~min}\right)$.

Concerning the data of $\mathrm{TSC}$, figure $2 \mathrm{~d}$ shows the effect of roasting temperature and roasting time on TSC when the extraction time fixed (6h); accordingly, the negative interaction effect between $\mathrm{X} 1$ and $\mathrm{X}_{2}$ was recorded; thus, the optimum of TSC was observed in the region at high temperature $200^{\circ} \mathrm{C}$ and less roasting time $10 \mathrm{~min}$. Moreover, Figure 2e presents the effect of roasting time and extraction time on the TSC when the roasting temperature was fixed at $200^{\circ} \mathrm{C}$; the TSC decreased with the increasing of the extraction time when the roasting time fixed, the same effect when the $\mathrm{X}_{3}$ fixed.
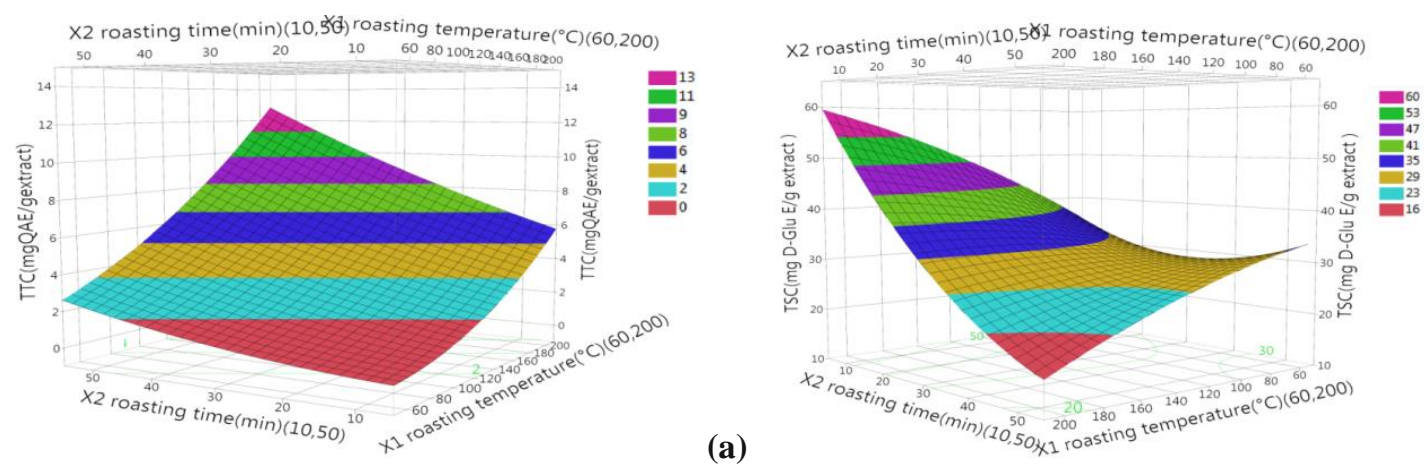

(d)
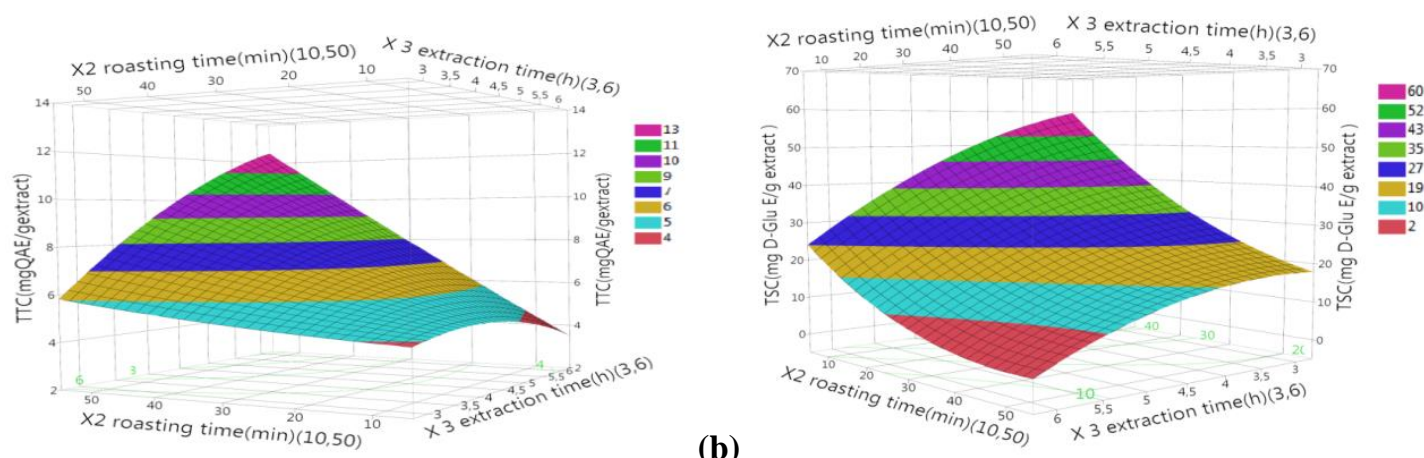

(e)
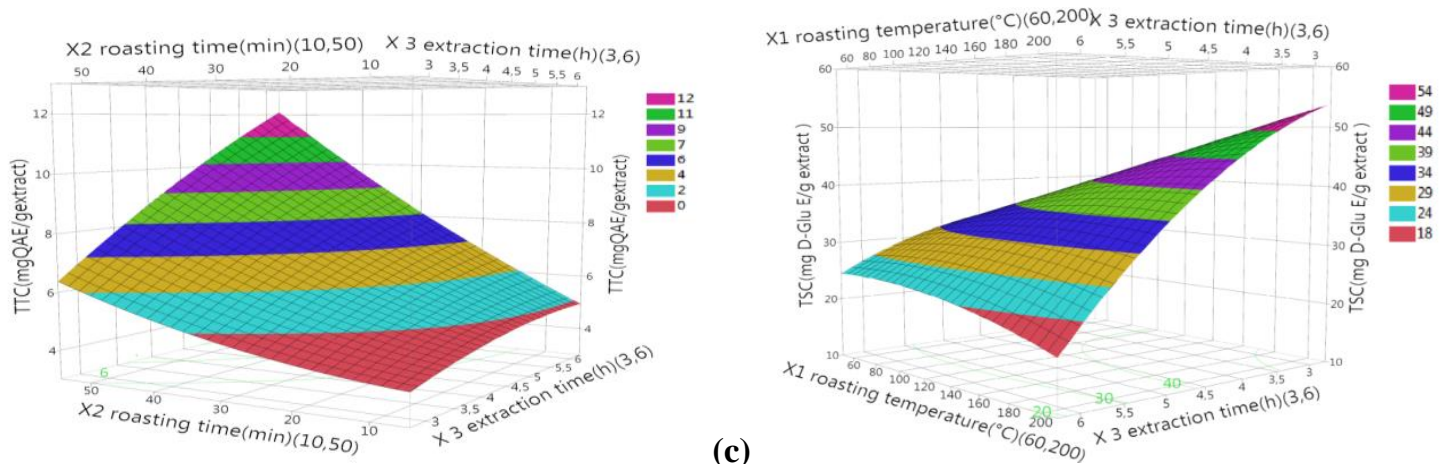

(f)

Figure 2. Response surface plots of roasting conditions of TTC (a,b, and c) and TSC (d, e, and f) of the Opuntia ficus Indica seeds extracts. 
According to Figure $2 \mathrm{f}$, who showed the influence of $\mathrm{X}_{1}$ and $\mathrm{X}_{3}$ on the TCS when the $\mathrm{X}_{2}$ was fixed at $10 \mathrm{~min}$, the TSC quickly decreased with the increase of $\mathrm{X}_{3}$ when the $\mathrm{X}_{1}$ fixed, but it slowly decreased when the increasing of $\mathrm{X}_{1}$ and $\mathrm{X}_{3}$ fixed. These results are similar to work showed that the content of free sugar generally decreased with increasing roasting temperature and time[41]. Because during the various roasting, nutrients such as carbonyl and amino molecules can be degraded by non-enzymatic browning reactions $[42,43]$. Therefore, the optimum ofTSC was at roasting temperature: $60{ }^{\circ} \mathrm{C}$, roasting time $50 \mathrm{~min}$, extraction time $5.12 \mathrm{~h}$ with $38.86 \mathrm{mg}$ D-Glu E /g extract predicted responses, and the desirability is d $=0.81($ Figure $4 \mathrm{~d})$.

3.5. Second-order polynomial model and interpretation of the response surface model of DPPH and ABTS assays.

ANOVA data from DPPH and ABTS assays based on the RMS are mentioned in Table 5 . The p-value of the models was $<0.0001$, which showed that the models were significant. In addition to that, the lack of fit was not significant because it was 0.0756 and 0.0504 for DPPH and ABTS assays, respectively, which confirms the adequacy of the models to predict the antioxidant activity from extracts seeds roasted. Moreover, the $\mathrm{R}^{2}$ and $\mathrm{R}^{2}$ adj were 0.999899 and 0.999718 , respectively, for DPPH, and they were 0.999813 and 0.999477 , respectively, for ABTS. Because of $\mathrm{R}^{2}>0.75$, which indicates the adequacy of the models[29]. Consequently, the second-order polynomial models were applied in equations 6 and 7 .

DPPH $(\mathrm{IC} 50)(\mu \mathrm{g} / \mathrm{mL})=231.41-132.5163 \mathrm{X}_{1}-74.9875 \mathrm{X}_{2}-24.31375 \mathrm{X}_{3}-10.35 \mathrm{X}_{1} * \mathrm{X}_{2} 2.9525 \mathrm{X}_{1} * \mathrm{X}_{3}+5.34 \mathrm{X}_{2}$ $* \mathrm{X}_{3}+7.28875 \mathrm{X}_{1} * \mathrm{X}_{1}+35.04125 \mathrm{X}_{2} * \mathrm{X}_{2}+39.67275 \mathrm{X}_{3} * \mathrm{X}_{3}$

$\operatorname{ABTS}(\operatorname{IC} 50)(\mu \mathrm{g} / \mathrm{mL})=682.44333-264.7125 \mathrm{X}_{1}-150.9038 \mathrm{X}_{2}-62.55125 \mathrm{X}_{3}-45.4125 \mathrm{X}_{1 *} \mathrm{X}_{2}-$ $21.3625 \mathrm{X}_{1} * \mathrm{X}_{3}+5.76 \mathrm{X}_{2} * \mathrm{X}_{3}+30.453333 \mathrm{X}_{1} * \mathrm{X}_{1}+72.955833 \mathrm{X}_{2} * \mathrm{X}_{2}+76.280833 \mathrm{X}_{3} * \mathrm{X}_{3}$

According to the statistical analysis of ANOVA for DPPH assay, roasting temperature $\left(\mathrm{X}_{1}\right)$, roasting time $\left(\mathrm{X}_{2}\right)$, and extraction time $\left(\mathrm{X}_{3}\right)$ had a negative significance $(\mathrm{p}$-value $<0.05)$ linear effect on the IC $\mathrm{C}_{50}$ of DPPH assays. Also, their quadratic effect $\mathrm{X}_{1} * \mathrm{X}_{1}, \mathrm{X}_{2} * \mathrm{X}_{2}$, and $\mathrm{X}_{3} *$ $\mathrm{X}_{3}$ had a positive significant $(\mathrm{p}$-value $<0.05)$ effect on the IC50 of DPPH assay.

Table 5. Data on the ANOVA of the regression coefficient and the terms of the model.

\begin{tabular}{l|l|l|l|l|l|l} 
Source & Coef & Sim of square & $\begin{array}{l}\text { Degree of } \\
\text { freedom }\end{array}$ & Mean square & F-value & p-value \\
\hline DPPHI $\left(\mathbf{C}_{\mathbf{5 0}}\right)$ & \multicolumn{5}{|l}{} \\
\hline Model & & 200403.00 & 9 & 22267.0 & 5520.906 & $<0.0001^{*}$ \\
\hline Constant & 231.41 & & & & & $<0.0001^{*}$ \\
\hline $\mathrm{X}_{1}$ & -132.5163 & 140484.45 & 1 & 140484.45 & 34831.88 & $<0.0001^{*}$ \\
\hline $\mathrm{X}_{2}$ & -74.9875 & 44985.00 & 1 & 44985.00 & 11153.63 & $<0.0001^{*}$ \\
\hline $\mathrm{X}_{3}$ & -24.31375 & 4729.27 & 1 & 4729.27 & 1172.580 & $<0.0001^{*}$ \\
\hline $\mathrm{X}_{1} * \mathrm{X}_{2}$ & -10.35 & 428.49 & 1 & 428.49 & 106.2403 & $<0.0001^{*}$ \\
\hline $\mathrm{X}_{1} * \mathrm{X}_{3}$ & -2.9525 & 34.87 & 1 & 34.87 & 8.6455 & $0.0322^{*}$ \\
\hline $\mathrm{X}_{2} * \mathrm{X}_{3}$ & 5.34 & 114.06 & 1 & 114.06 & 28.2808 & $0.0031^{*}$ \\
\hline $\mathrm{X}_{1} * \mathrm{X}_{1}$ & 7.28875 & 196.16 & 1 & 196.16 & 48.6354 & $0.0009^{*}$ \\
\hline $\mathrm{X}_{2} * \mathrm{X}_{2}$ & 35.04125 & 4533.74 & 1 & 4533.74 & 1124.102 & $<0.0001^{*}$ \\
\hline $\mathrm{X}_{3} * \mathrm{X}_{3}$ & 39.67275 & 5811.72 & 1 & 5811.72 & 1440.964 & $<0.0001^{*}$ \\
\hline Residual & & 20.17 & 5 & 4.0 & & \\
\hline Total & & 200423.16 & 14 & & & 12.3883 \\
\hline Lack of fit & & 19.136275 & 3 & 6.37876 & 0.0756 \\
\hline Pure Error & & 1.029800 & 2 & 0.51490 & & \\
\hline Total Error & & 20.166075 & 5 & & & \\
\hline $\mathrm{R}^{2}$ & 0.999899 & & & & & \\
\hline Radj & 0.999718 & & & & & \\
\hline
\end{tabular}




\begin{tabular}{|c|c|c|c|c|c|c|}
\hline Source & Coef & Sim of square & $\begin{array}{l}\text { Degree of } \\
\text { freedom }\end{array}$ & Mean square & F-value & p-value \\
\hline \multicolumn{7}{|l|}{$\operatorname{ABTS}\left(\mathrm{IC}_{50}\right)$} \\
\hline Model & & 823930.42 & 9 & 91547.8 & 2976.325 & $<0.0001 *$ \\
\hline Constant & 682.44333 & & & & & $<0.0001^{*}$ \\
\hline $\mathrm{X}_{1}$ & -264.7125 & & 1 & -264.7125 & 18225.15 & $<0.0001 *$ \\
\hline$X_{2}$ & -150.9038 & & 1 & -150.9038 & 5922.736 & $<0.0001^{*}$ \\
\hline $\mathrm{X}_{3}$ & -62.55125 & & 1 & -62.55125 & 1017.640 & $<0.0001^{*}$ \\
\hline $\mathrm{X}_{1} * \mathrm{X}_{2}$ & -45.4125 & & 1 & -45.4125 & 268.1903 & $<0.0001 *$ \\
\hline $\mathrm{X}_{1} * \mathrm{X}_{3}$ & -21.3625 & & 1 & -21.3625 & 59.3467 & $<0.0001^{*}$ \\
\hline $\mathrm{X}_{2} * \mathrm{X}_{3}$ & 5.76 & & 1 & 5.76 & 4.3146 & 0.0924 \\
\hline $\mathrm{X}_{1} * \mathrm{X}_{1}$ & 30.453333 & & 1 & 30.453333 & 111.3268 & $0.0001 *$ \\
\hline $\mathrm{X}_{2} * \mathrm{X}_{2}$ & 72.955833 & & 1 & 72.955833 & 638.9256 & $<0.0001 *$ \\
\hline $\mathrm{X}_{3} * \mathrm{X}_{3}$ & 76.280833 & & 1 & 76.280833 & 698.4914 & $<0.0001^{*}$ \\
\hline Residual & & 153.79 & 5 & 30.8 & & \\
\hline Total & & 824084.21 & 14 & & & \\
\hline Lack of fit & & 148.58192 & 3 & 49.5273 & 19.0071 & 0.0504 \\
\hline Pure Error & & 5.21147 & 2 & 2.6057 & & \\
\hline Total Error & & 153.79339 & 5 & & & \\
\hline $\mathrm{R}^{2}$ & 0.999813 & & & & & \\
\hline $\operatorname{Radj}^{2}$ & 0.999477 & & & & & \\
\hline
\end{tabular}

* Significant atp-value $<0.05$

Moreover, the interaction effect $\mathrm{X}_{2} * \mathrm{X}_{3}$ had a significant positive effect on DPPH ( IC50) because its $\mathrm{p}$-value is equal 0.0031 ,on the contrary, the interaction effects $\mathrm{X}_{1} * \mathrm{X}_{2}$ and $\mathrm{X}_{1}$ * $\mathrm{X}_{3}$ had a negative significant(p-value $\left.<0.05\right)$ effects on IC50 DPPH. Concerning data of ANOVA for ABTS assay. The three factors $X_{1}, X_{2}$, and $X_{3}$ had a negative linear effect on $\mathrm{IC}_{50}$ ABTS (p-value<0.05); in addition to that, their quadratic effects had a positive significant effect on $\mathrm{IC}_{50} \mathrm{ABST}(\mathrm{p}$-value<0.05). In addition to that, the interaction effect between roasting temperature $\left(\mathrm{X}_{1}\right)$ and extraction time $\left(\mathrm{X}_{3}\right)$ had a significant negative effect on IC50 ABTS (pvalue $<0.0001)$. On the contrary, the interaction effect $\mathrm{X}_{2} * \mathrm{X}_{3}$ had not significant because its $\mathrm{p}$ value is 0.0924 .

\subsection{Response surface methodology (RSM) analysis.}

The response surface (3D) of regression equations 6 and 7 were constructed using RMS and are shown in Figure3. The antioxidant activity is inversely proportional to $\mathrm{IC}_{50}$. Moreover, Figure $3 \mathrm{a}$ and Figure $3 \mathrm{~d}$ show the effect of roasting time $\left(\mathrm{X}_{2}\right)$ and roasting temperature $\left(\mathrm{X}_{1}\right)$ on the $\mathrm{IC}_{50}$ for DPPH and ABTS assays, respectively, when the extraction time $\left(\mathrm{X}_{3}\right)$ was fixed at 4.5h. We observed that the antioxidant activity by DPPH and ABTS assays increased significantly with the increasing of roasting time $\left(\mathrm{X}_{2}\right)$ and roasting temperature $\left(\mathrm{X}_{1}\right)$ because of the $\mathrm{IC}_{50}$ of DPPH and ABTS assays was decreased. Therefore, the maximal of the antioxidant activity for the two assays were in the at a high roasting temperature region $\left(\mathrm{X}_{1}\right)$ and roasting time $\left(\mathrm{X}_{2}\right)$. Additionally, the effects of roasting time $\left(\mathrm{X}_{2}\right)$ and extraction time $\left(\mathrm{X}_{3}\right)$ on $\mathrm{IC}_{50}$ when the roasting temperature was fixed $\left(200^{\circ} \mathrm{C}\right)$ are presented in Figure $3 \mathrm{~b}$ and Figure $3 \mathrm{e}$ for DPPH and ABTS assays, respectively. The negative effects significant of $\mathrm{X}_{2}$ and $\mathrm{X}_{3}$ on $\mathrm{IC}_{50}$ for DPPH and ABTS are recorded. Thus, the antioxidant activity increased with the increasing extraction time and roasting temperature for the two assays. Figure $3 \mathrm{c}$ and Figure $3 \mathrm{f}$ showed the effects of roasting temperature and extraction time when the roasting time was fixed(50min) on IC50 of DPPH and ABTS, respectively. We observed that the antioxidant activity increased for the two assays with the increasing of two factors $\mathrm{X}_{1}$ and $\mathrm{X}_{3}$ because the $\mathrm{IC}_{50}$ value was decreased. Moreover, the optimal antioxidant activity was at a strong roasting temperature and extraction time for DPPH and ABTS assays. Based on the desirability function, the maximum of antioxidant activity by DPPH assay was at a roasting temperature 
$\left(\mathrm{X}_{1}=200{ }^{\circ} \mathrm{C}\right)$, roasting time $\left(\mathrm{X}_{2}=47.85 \mathrm{~min}\right)$, and extraction time $\left(\mathrm{X}_{3}=4.91\right)$ with $98.226 \%$ of inhibition, which matches $73.21 \mu \mathrm{g} / \mathrm{mL}$ predicted response, as well as, the desirability is $\mathrm{d}=0.84$ (Figure $4 \mathrm{e}$ ).
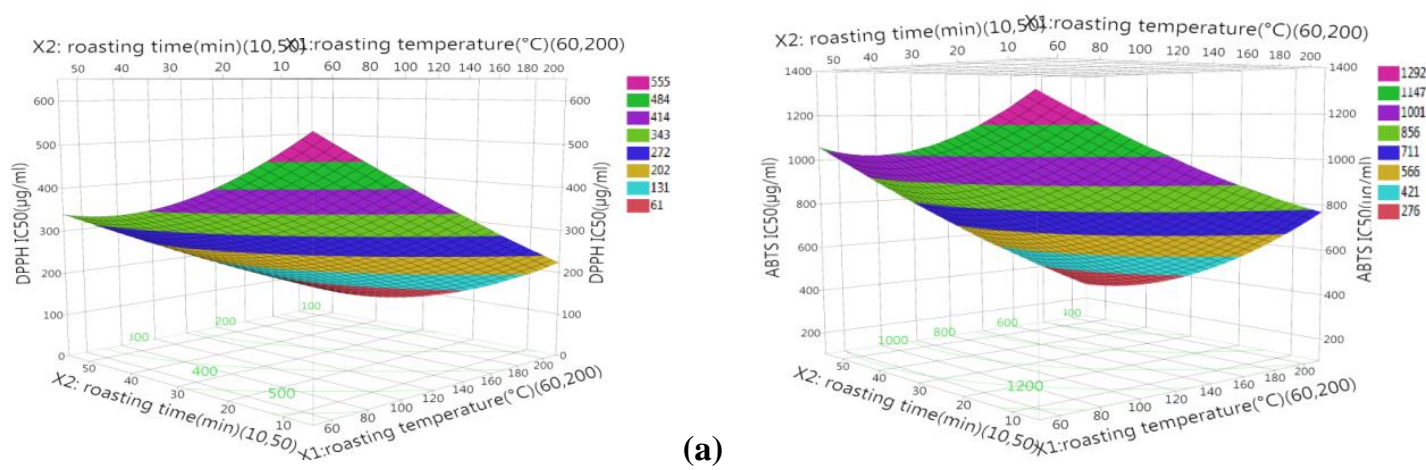

(d)


(e)
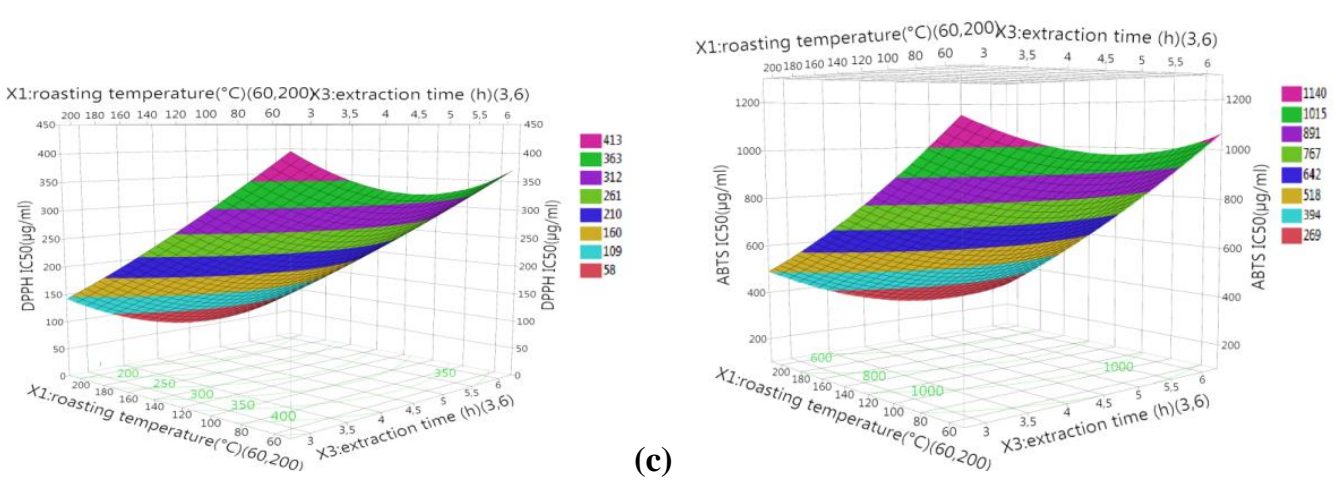

(f)

Figure 3. Response surface plots of roasting conditions of DPPH $\operatorname{IC}_{50}\left(\mathrm{a}, \mathrm{b}\right.$, and c) and $\mathrm{ABTS} \mathrm{IC}_{50}(\mathrm{~d}, \mathrm{e}$, and f) of the Opuntia ficus Indica seeds extracts.

For ABTS assay, the optimal for the antioxidant activity was at a roasting temperature $\left(X_{1}=200^{\circ} \mathrm{C}\right)$, roasting time $\left(X_{2}=49 . \mathrm{min}\right)$, and extraction time $(X 3=5.28)$ with $97.38 \%$ of inhibition, which matches $305.57 \mu \mathrm{g} / \mathrm{mL}$ predicted response, as well as, the desirability is $\mathrm{d}=0.907$ (Figure 4f.).

These results confirm those found by several works. Lin et al. [37] showed that the strongest antioxidant activity was recorded at high roasting temperature for ethanolic almond extract (Prunus dulcis) kernel, as well as the power for scavenging DPPH radical during the roasting temperature at $200{ }^{\circ} \mathrm{C}$ for 20 min was more than the raw sample. In addition, Chandrasekara and Shahid i[32] showed that the antioxidant activity for DPPH radical increased significantly with increasing the roasting temperature for soluble phenolic testa extract. Concerning ABTS assays. Yin et al. [35] indicated that the scavenging (ABTS) increased during the roasting at $130{ }^{\circ} \mathrm{C}-140{ }^{\circ} \mathrm{C}$ after $60 \mathrm{~min}$. In addition, Gao et al. [44] reported that the activity (ABTS) increased significantly at $160{ }^{\circ} \mathrm{C}$ for $10 \mathrm{~min}$ of roasting compared to raw extract. 
Table 6. Experimental and predicted results at conditions optimal.

\begin{tabular}{l|l|l|l|l|l} 
Responses & $\begin{array}{l}\mathbf{X}_{1} \text { roasting } \\
\text { temperature }\left({ }^{\circ} \mathbf{C}\right)\end{array}$ & $\begin{array}{l}\mathbf{X}_{2} \text { roasting } \\
\text { time }(\mathbf{m i n})\end{array}$ & $\begin{array}{l}\mathbf{X}_{3} \text { extraction } \\
\text { time(h) }\end{array}$ & $\begin{array}{l}\text { Predicted } \\
\text { value }\end{array}$ & $\begin{array}{l}\text { Experimental } \\
\text { value }\end{array}$ \\
\hline $\begin{array}{l}\text { Total phenolicContents } \\
(\mathrm{mgGAE} / \mathrm{gextract})\end{array}$ & $200^{\circ} \mathrm{C}$ & $50 \mathrm{~min}$ & $5.49 \mathrm{~h}$ & 106.23 & $103.5 \pm 0.76$ \\
\hline $\begin{array}{l}\text { Total flavonoids } \\
\text { content(mgQE/gextract) }\end{array}$ & $200^{\circ} \mathrm{C}$ & $50 \mathrm{~min}$ & $3.16 \mathrm{~h}$ & 106.85 & $104.29 \pm 0.54$ \\
\hline $\begin{array}{l}\text { Total TanninsContent } \\
(\mathrm{mgQAE} / \mathrm{gextract})\end{array}$ & $200^{\circ} \mathrm{C}$ & $50 \mathrm{~min}$ & $6 \mathrm{~h}$ & 11.30 & $10,16 \pm 0.89$ \\
\hline $\begin{array}{l}\text { Total sucrs Content }(\mathrm{mg} \\
\text { D-Glu Egextract })\end{array}$ & $60^{\circ} \mathrm{C}$ & $50 \mathrm{~min}$ & $5.12 \mathrm{~h}$ & 38.86 & $40.35 \pm 0.99$ \\
\hline \begin{tabular}{l} 
DPPH IC50 $(\mu \mathrm{g} / \mathrm{mL})$ \\
\hline ABTSIC $50(\mu \mathrm{g} / \mathrm{mL})$
\end{tabular} & $200^{\circ} \mathrm{C}$ & $47.85 \mathrm{~min}$ & $4.91 \mathrm{~h}$ & 73.21 & $75.48 \pm 0.85$ \\
\hline
\end{tabular}

These results can be justified as follows: during roasting, the antioxidants characteristics can be enhanced due to a reaction between amino acids and the reducing sugars; this reaction produced a new molecule named Maillard reaction products (MRPs), as well as the degradation of the heat-labile antioxidants compounds [32,45]. Moreover, during the thermal treatment, the bound antioxidant phenol and bound polymeric compounds of plants may be degraded and released, which leads to an increase in the antioxidant capacity[46]. Furthermore, the resultant melanoidin and Maillard reaction products had a higher antioxidant activity, which depends on the presence of reductone-type structures[47], as well as, roasting improves the solubility of non-phenolic molecules[48].

\subsection{Verification and comparisons of predicted models and experimental values.}

The validity of the predictive models was checked by comparing the results predicted and experimental data. This verification was carried out using the experimental conditions of the maximal response values. Based on data from Table 6, the predicted results are close to experimental results.

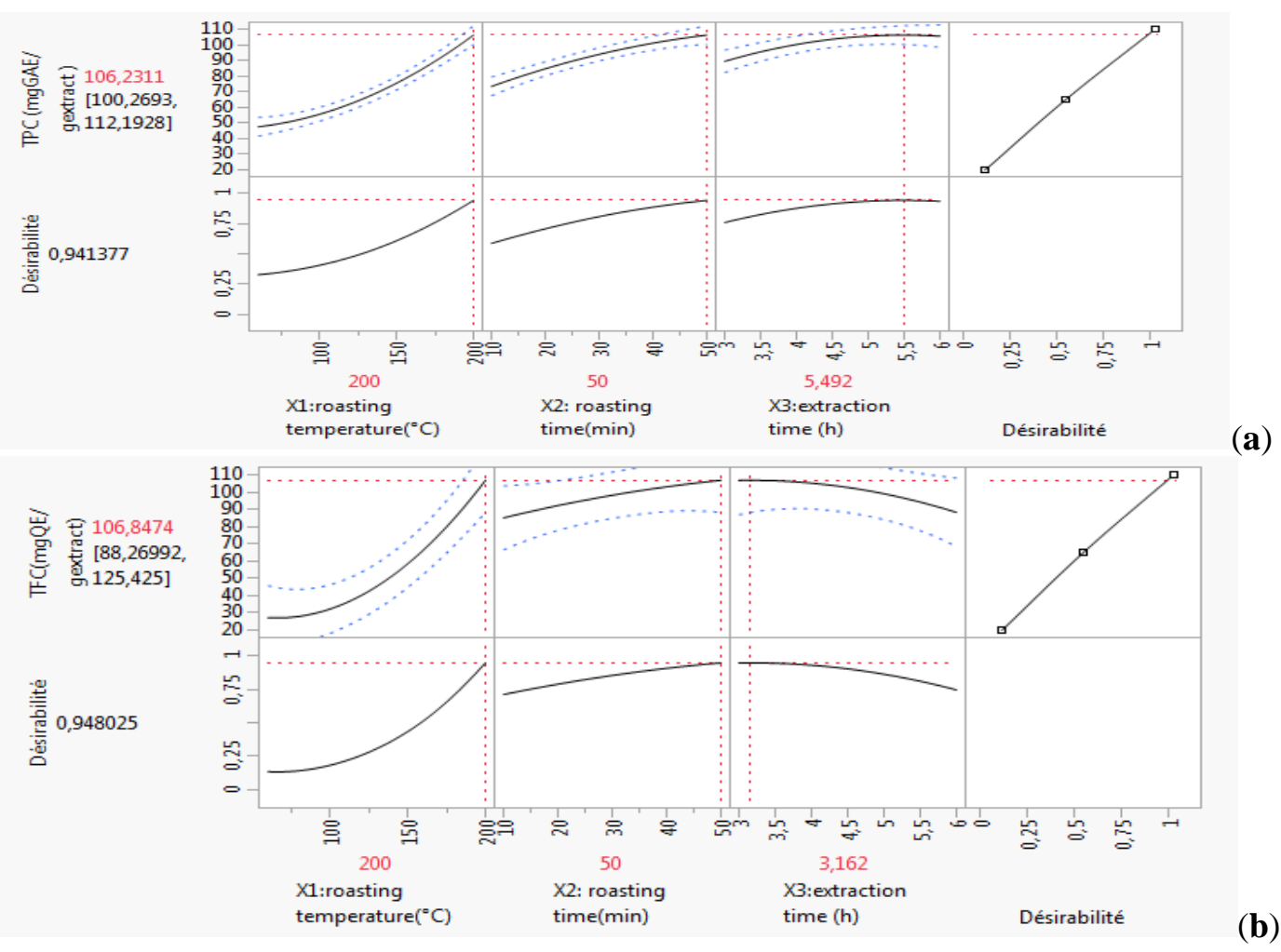




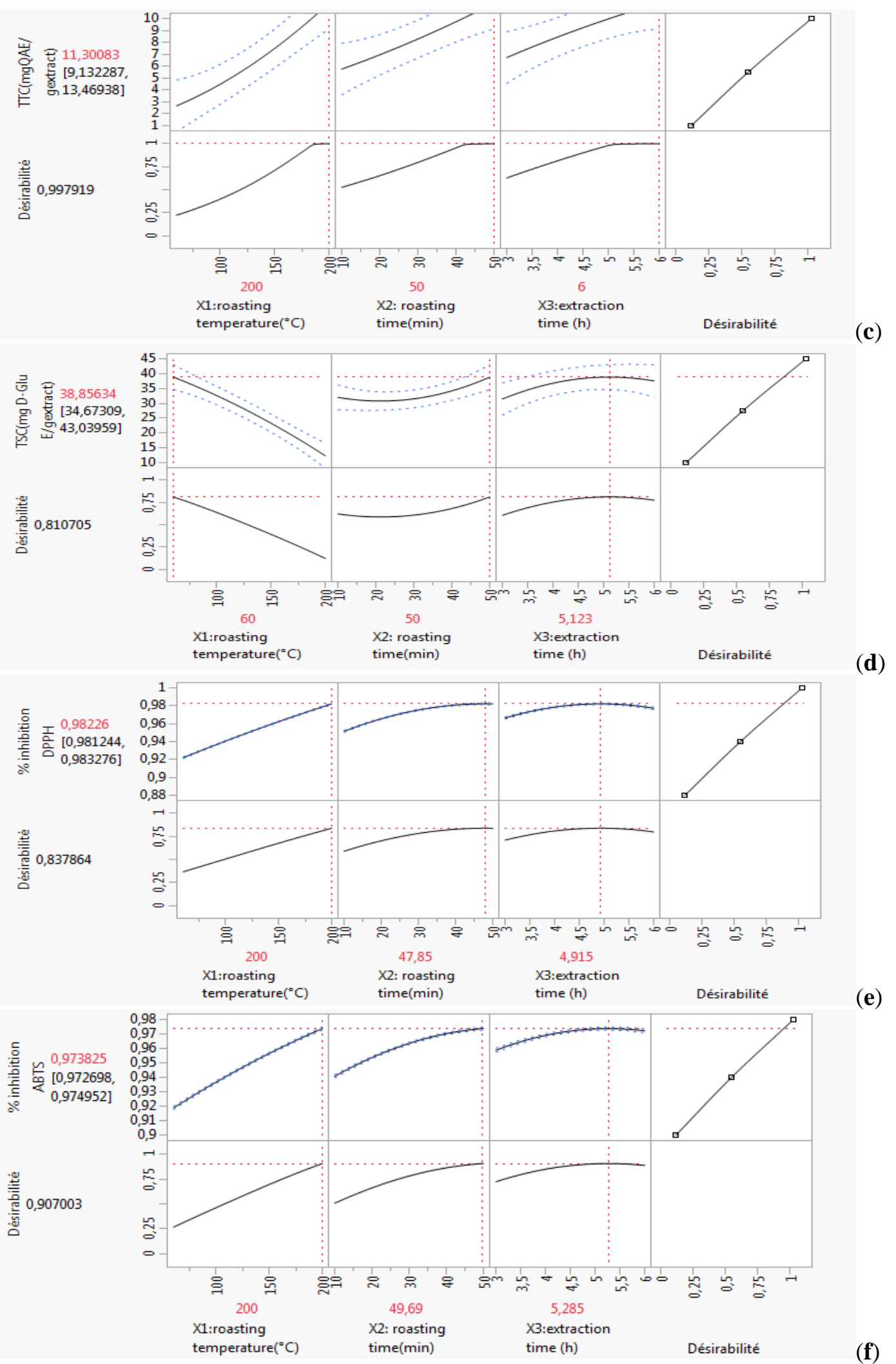

Figure 4. Desirability results for a: TPC, b: TFC, c: TTC, d:TSC, e: DPPH, and f: ABTS.

\subsection{Correlation matrix.}

The correlation coefficients and the p-values of all responses studied were presented in Table 7 and Table 8, respectively. In addition, the antioxidant activities (ABTS (1/IC50); DPPH (1/IC50)) expressed the power to inhibit ABTS and DPPH radical, respectively; they are inversely proportional to $\mathrm{IC}_{50}$. 
Table 7. Pearson's correlation matrix between antioxidant activities and bioactive compounds.

\begin{tabular}{l|r|r|r|r|r|r}
\multicolumn{1}{c|}{ Variable } & \multicolumn{1}{c|}{ TPC } & \multicolumn{1}{c|}{ TFC } & \multicolumn{1}{c|}{ TTC } & \multicolumn{1}{c|}{ TSC } & DPPH (1/IC50) & ABTS(1/IC50) \\
\hline TPC & $\mathbf{1}$ & & & & & \\
\hline TFC & $\mathbf{0 . 9 1 7}$ & $\mathbf{1}$ & & & & \\
\hline TTC & $\mathbf{0 . 9 4 9}$ & $\mathbf{0 . 8 3 1}$ & $\mathbf{1}$ & & & \\
\hline TSC & $\mathbf{- 0 . 5 6 0}$ & -0.358 & $\mathbf{- 0 . 6 0 7}$ & $\mathbf{1}$ & & \\
\hline DPPH (1/IC50) & $\mathbf{0 . 9 1 7}$ & $\mathbf{0 . 8 3 6}$ & $\mathbf{0 . 8 9 1}$ & $\mathbf{- 0 . 6 5 0}$ & $\mathbf{1}$ & $\mathbf{0 . 9 9 2}$ \\
\hline ABTS (1/IC 50$)$ & $\mathbf{0 . 9 2 0}$ & $\mathbf{0 . 8 0 2}$ & $\mathbf{0 . 9 0 7}$ & $\mathbf{- 0 . 6 9 5}$ & $\mathbf{1}$
\end{tabular}

The results in bold are different from 0 at a significance level alpha $=0.05$.

Table 8. p-value of coefficient correlations matrix.

\begin{tabular}{|c|c|c|c|c|c|c|}
\hline Variables & TPC & TFC & TTC & TSC & DPPH(1/IC50) & $\operatorname{ABTS}\left(1 / \mathrm{IC}_{50}\right)$ \\
\hline TPC & $\mathbf{0}$ & & & & & \\
\hline TFC & $<0.0001$ & $\mathbf{0}$ & & & & \\
\hline TTC & $<0.0001$ & 0.000 & $\mathbf{0}$ & & & \\
\hline TSC & 0.030 & 0.191 & 0.016 & $\mathbf{0}$ & & \\
\hline $\mathrm{DPPH}\left(1 / \mathrm{IC}_{50}\right)$ & $<0.0001$ & 0.000 & $<0.0001$ & 0.009 & $\mathbf{0}$ & \\
\hline $\operatorname{ABTS}\left(1 / \mathrm{IC}_{50}\right)$ & $<0.0001$ & 0.000 & $<0.0001$ & 0.004 & $<0.0001$ & $\overline{\mathbf{0}}$ \\
\hline
\end{tabular}

The results in bold are different from 0 at a significance level alpha $=0.05$.

As can be seen from Tables7 and 8, the strong positive correlations(p-value $<0.0001$ ) between the phytochemical compounds(TPC, TFC, TTC) and the antioxidant power were recorded. The coefficient correlations of TPC were 0.917 and 0.920 with free radical scavenging DPPH and ABTS, respectively. These positive correlations mean that the antioxidant activity of Opuntia ficus Indica seeds extracts can be attributed to the presence of polyphenol (TPC). They were also reported by various researchers [49,50]. Strong significant positive correlation between TFC and antioxidant power between DPPH $\left(1 / \mathrm{IC}_{50}\right)\left(\mathrm{r}^{2}=0.836\right)$, and ABTS $\left(1 / \mathrm{IC}_{50}\right)\left(\mathrm{r}^{2}=0.802\right)$ was observed. Moreover, it was found that the TTC also had a significant positive correlation ( $\mathrm{p}$-value $<0.0001)$ between $\mathrm{DPPH}\left(1 / \mathrm{IC}_{50}\right)$ and $\mathrm{ABTS}\left(1 / \mathrm{IC}_{50}\right)$. Accordingly, these correlations are confirmed by high positive significant correlations(pvalue $<0.05$ ) between TPC, TFC, and TTC. We also observed that the TSC was not significant with antioxidant activity ( $p$-value $>0.05$ ). In addition, the higher positive correlation was significant between 2 antioxidant activity $\left(\mathrm{r}^{2}=0.992\right)$ and showed that the same antioxidant compounds in our samples are responsible for the scavenging activity of 2 free radicals ABTS and DPPH.

\subsection{Principal component analysis PCA.}

Figure 6 showed the projections of the results of experimental assays (15 extracts) by the factorial plan (F1-F2), according to PCA. The first essential component, F1, explains $83.38 \%$ of the information, and the second shows $11.64 \%$ of the information. Thus, the cumulative percentage was $95.02 \%$; it is more than 50\%, which indicated that the linear combination is already representative of the variables. The correlations between all responses are shown in Figure 5 by the plane formed by axes F1 and F2. Therefore, the F1 plan was constructed by the positive correlation between TFC, TPC, TTC, ABTS (1/IC50), and DPPH (1/IC50). But the F2 plan was formed by TSC (Figure 5). The extracts of this study were separated into 3 groups based on responses results in Figure 6. 




Figure 5. Principal Component Analysis factorial plan carried out on the values (TFC, TPC, TSC, TTC, ABTS (1/IC50), and DPPH(1/IC50)).

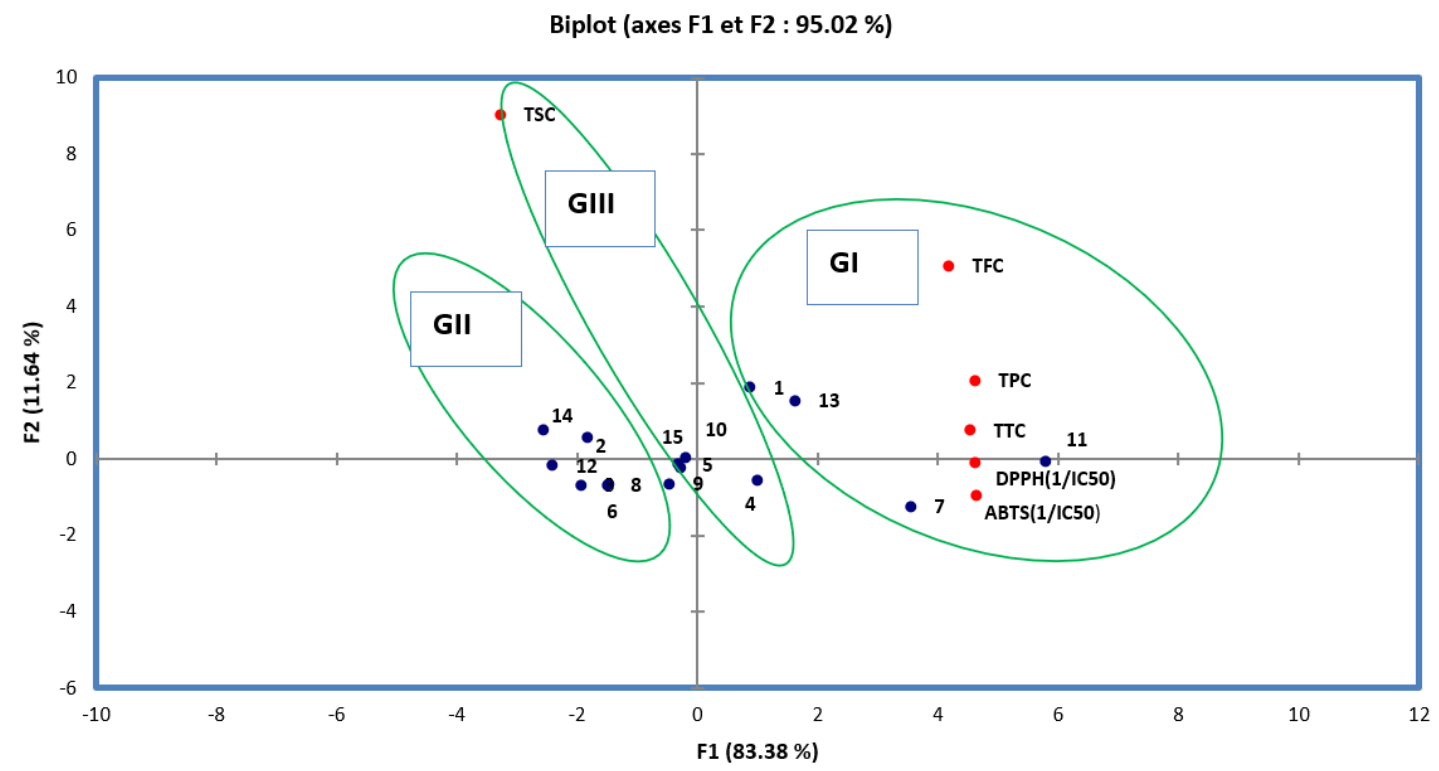

DPPH (1/ IC s0 $_{0}$; ABTS (1/ IC 50 ) ,. GI: Group I; GII: Group II; G III; Group III.

Figure 6. Projection the factorial plan $(\mathrm{F} 1 \times \mathrm{F} 2)$ of the individual's variable.

Group I is composed of four extracts $(1,13,7,11)$; these extracts had high values of TPC TFC, and TCC; also, they had a high antioxidant capacity by ABTS and DPPH assays. On the contrary, they had a lower value of TSC. Group II contains 6 extracts $(8,3,6,2,12$, and 14). The extracts of this group are characterized by the low values of TPC, TFC, and TTC, but they had a higher value of TSC. Its antioxidant capacity is low compared to other groups. Group III is formed by five extracts $(5,10,9,4,15)$. The extracts of this group are characterized by a higher value of TSC and by medium values of TPC, TFC, and TTC. Consequently, their antioxidant capacity is medium compared to $\mathrm{G} 1$. Group I contains extracts characterized by a strong roasting temperature of $200{ }^{\circ} \mathrm{C}$, which indicated that their antioxidant activity is stronger and more than the extract of G II and G III. Therefore, roasting can increase the extraction of bioactive molecules responsible for antioxidants activity. 


\subsection{Hierarchical clustering analysis HCA.}

According to HCA, extracts were classified by the squared Euclidean and Wards method $i$ to estimate the similarity measure. HCA was used to evaluate the correlation between the extracts and to present similarities of 15 extracts (experiment assays) based on data of antioxidant contents and antioxidant activity, as indicated in the dendrogram in Figure 7. According to bioactive molecules, the 15 extracts were clustered into three Clusters. Cluster I contains 4 extracts $(1,13,7,11)$ representing for $26.66 \%$ of the total extracts characterized by a high range mean of TPC, TFC, and TTC $87.74 \mathrm{mg} \mathrm{GAE} / \mathrm{g}$ extract, $90.36 \mathrm{mg}$ QE/g extract, and $7.06 \mathrm{mg}$ QAE/g extract, respectively, as well as, they had a stronger antioxidants capacity. Cluster II, the largest cluster formed using 6 extracts, namely 8, 3, 6, 2, 12, and 14, accounted for $40 \%$ of total extracts; these extracts had the lowest mean value of TPC, TFC, and TTC $35.57 \mathrm{mg} \mathrm{GAE} / \mathrm{g}$ extract, $33.60 \mathrm{mg} \mathrm{QE} / \mathrm{g}$ extract, and $1.62 \mathrm{mg}$ QAE/g extract respectively. Also, they had a high mean level of TSC $33.73 \mathrm{mg}$ D-Glu E/g extract, and they are characterized by a low antioxidant activity by DPPH and ABTS. From the cluster analysis, Cluster III contained four extracts, namely 5,10,9, 4, and 15 representing for $33.33 \%$ of the total extracts, with a medium mean values of antioxidant compounds TPC, TFC, TTC, and TSC $57.91 \mathrm{mg} \mathrm{GAE} / \mathrm{g}$ extract, $44.46 \mathrm{mg} \mathrm{QE} / \mathrm{g}$ extract, $4.06 \mathrm{mg}$ QAE/g extract, and $28.06 \mathrm{mg}$ D-Glu E/g extract respectively, as well as, a medium antioxidant power. These results are in agreement with the data of the PCA, in which the distribution of all extracts on the score plot indicates a similar trend. Furthermore, the PCA results were consistent with those of HCA.

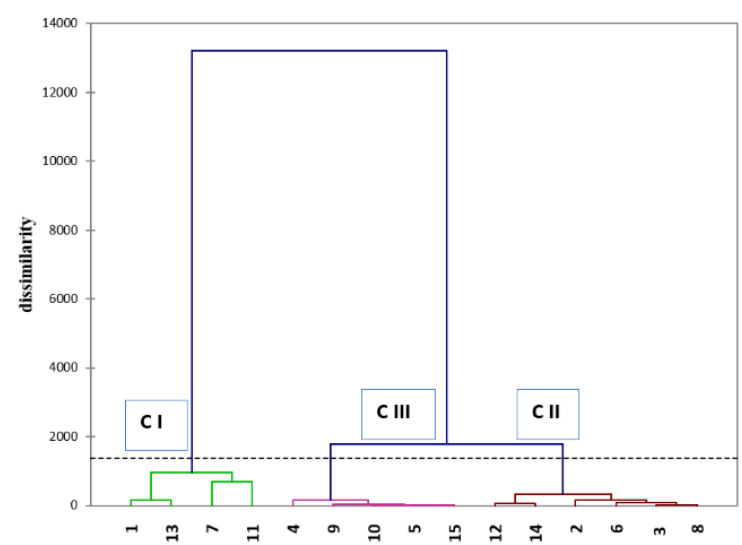

CI: Cluster I; CII: Cluster II; C III; Cluster III.

Figure 7. Dendrogram of the extracts tested founded by HCA using bioactive and their antioxidant capacities.

\section{Conclusions}

RSM (response surface method) was employed to optimize the conditions of the dry thermal processing in order to determine the optimum levels of bioactive molecules and their antioxidant activities from Opuntia ficus Indica seeds extracts. The results showed that the levels of bioactive molecules increased significantly with increasing roasting temperature and roasting time. Moreover, the experimental values generated based on the optimized roasting factors were found close to the predicted values. Therefore, this work suggests that the models obtained can be used to optimize the roasting temperature, roasting time, and extraction time for the extraction of bioactive molecules from Opuntia ficus Indica seeds. PCA indicated a positive correlation between bioactive molecules and antioxidant activities (ABTS, DPPH). Furthermore, HCA showed that the interrelatedness between extracts. Therefore, roasted 
Opuntia ficus Indica seeds may be considered as traditional food with strong antioxidant power for the production of functional foods.

\section{Funding}

This research received no external funding.

\section{Acknowledgments}

We thank all colleagues of the Laboratory of Materials, Nanotechnology, and Environment, Faculty of Sciences, Mohammed V University.

\section{Conflicts of Interest}

The authors declare no conflict of interest.

\section{References}

1. Jorge, A. J.; De La Garza, T. H.; Alejandro, Z. C.; Ruth, B. C.; Noé, A. C. The optimization of phenolic compounds extraction from cactus pear (Opuntia ficus-indica) skin in a reflux system using response surface methodology. Asian Pac. J. Trop. Bio. 2013, 3, 436-442, https://doi.org/10.1016/S2221-1691(13)600933.

2. Benayad, Z.; Martinez-Villaluenga, C.; Frias, J.; Gomez-Cordoves, C.; Es-Safi, N. E. Phenolic composition, antioxidant and anti-inflammatory activities of extracts from Moroccan Opuntia ficus-indica flowers obtained by different extraction methods. Ind. Crops Prod. 2014, 62, 412-420, https://doi.org/10.1016/j.indcrop.2014.08.046.

3. Marin-Bustamante, M. Q.; Chanona-Pérez, J. J.; Gvemes-Vera, N.; Arzate-Vázquez, I.; Perea-Flores, M. J.; Mendoza-Pérez, J. A.;Casarez-Santiago, R. G. Evaluation of physical, chemical, microstructural and micromechanical properties of nopal spines (Opuntia ficus-indica). Ind. Crops Prod. 2018, 123, 707-718, https://doi.org/10.1016/j.indcrop.2018.07.030.

4. Bensadón, S.; Hervert-Hernández, D.; Sáyago-Ayerdi, S. G.; Goñi, I. By-products of Opuntia ficus-indica as a source of antioxidant dietary fiber. Plant Foods Hum. Nutr. 2010, 65, 210-216, https://doi.org/10.1007/s11130-010-0176-2.

5. Ammar, I.; Salem, M. B.; Harrabi, B.; Mzid, M.; Bardaa, S.; Sahnoun, Z.; Ennouri, M. Anti-inflammatory activity and phenolic composition of prickly pear (Opuntia ficus-indica) flowers. Ind. Crops Prod. 2018, 112, 313-319, https://doi.org/10.1016/j.indcrop.2017.12.028.

6. Amrane-Abider, M.; Nerin, C.; Cannelas, E.; Zeroual, B.; Hadjal, S.; Louaileche, H.Prickly pear (Opuntia ficus-indica) seeds as a source of phenolic compounds: microwave-assisted extraction optimization and effect on food lipid oxidations. The Annals of the University Dunarea de Jos of Galati. Fascicle VI-Food Technology 2018, 42, 23-35, https://doi.org/10.1111/jfpp.13437.

7. Ammar, I.; Ennouri, M.; Attia, H. Phenolic content and antioxidant activity of cactus (Opuntia ficus-indica L.) flowers are modified according to the extraction method. Ind. Crops Prod. 2015, 64, 97-104, https://doi.org/10.1016/j.indcrop.2014.11.030.

8. Al Juhaimi, F.; Özcan, M. M.; Uslu, N.; Ghafoor, K.; Babiker, E. E. Effect of microwave heating on phenolic compounds of prickly pear (Opuntia ficus-indica L.) seeds. J. Food Process. Pres. 2018, 42, 1435-1449, https://doi.org/10.1111/jfpp.13437.

9. Brahmi, F.; Haddad, S.; Bouamara, K..; Yalaoui-Guellal, D.; Prost-Camus, E.; de Barros, J. P. P.; Lizard, G. Comparison of chemical composition and biological activities of Algerian seed oils of Pistacia lentiscus L., Opuntia ficus indica (L.) mill. and Argania spinosa L. Skeels. Ind. Crops. Prod. 2020, 151, 112456, https://doi.org/10.1016/j.indcrop.2020.112456.

10. Fikry, M.; Yusof, Y. A.; M Al-Awaadh, A.; Abdul Rahman, R.; Chin, N. L.; Ghazali, H. M. Antioxidative and quality properties of full-fat date seeds brew as influenced by the roasting conditions. Antioxidants 2019, 8, 226, https://doi.org/10.3390/antiox8070226.

11. Carciochi, R. A.; Galván D' Alessandro, L.; Manrique, G. D. Effect of roasting conditions on the antioxidant compounds of quinoa seeds. Int. J. Food. Sci. \& Tech. 2016, 51, 1018-1025, https://doi.org/10.1111/ijfs.13061. 
12. Khan, A.; Saini, C. S. Effect of roasting on physicochemical and functional properties of flaxseed flour. Cogent. Eng. 2016, 3, 1145566, https://doi.org/10.1080/23311916.2016.1145566.

13. Açar, Ö. Ç.; Gökmen, V.; Pellegrini, N.; Fogliano, V. Direct evaluation of the total antioxidant capacity of raw and roasted pulses, nuts and seeds. Eur. Food Res. Technol. 2009, 229, 961-969, https://doi.org/10.1007/s00217-009-1131-z.

14. Sharma, K.; Ko, E. Y.; Assefa, A. D.; Ha, S.; Nile, S. H.; Lee, E. T.; Park, S. W. Temperature-dependent studies on the total phenolics, flavonoids, antioxidant activities, and sugar content in six onion varieties. $J$ Food. Drug. Anal. 2015, 23, 243-252, https://doi.org/10.1016/j.jfda.2014.10.005.

15. Vujasinovic, V.; Djilas, S.; Dimic, E.; Basic, Z.; Radocaj, O. The effect of roasting on the chemical composition and oxidative stability of pumpkin oil. Eur J Lipid Sci Technol 2012, 114, 568-574, https://doi.org/10.1002/ejlt.201100158.

16. Alberti, A.; Zielinski, A. A. F.; Zardo, D. M.; Demiate, I. M.; Nogueira, A.; Mafra, L. I. Optimisation of the extraction of phenolic compounds from apples using response surface methodology. Food chemistry 2014, 149, 151-158,https://doi.org/10.1016/j.foodchem.2013.10.086.

17. Singleton, V. L.; Orthofer, R.; Lamuela-Raventós, R. M. Analysis of total phenols and other oxidation substrates and antioxidants by means of folin-ciocalteu reagent. Method enzymol. 1999, 299, 152-178, https://doi.org/10.1016/S0076-6879(99)99017-1.

18. Yeddes, N.; Chérif, J. K.; Guyot, S.; Sotin, H.; Ayadi, M. T. Comparative study of antioxidant power, polyphenols, flavonoids and betacyanins of the peel and pulp of three Tunisian Opuntia forms. Antioxidants 2013, 2, 37-51, https://doi.org/10.3390/antiox2020037.

19. Sun, B.; Ricardo-da-Silva, J. M.; Spranger, I. Critical factors of vanillin assay for catechins and proanthocyanidins. J. Agric. Food. Chem. 1998, 46, 4267-4274, https://doi.org/10.1021/jf980366j.

20. Chaiwut, P.; Pintathong, P.; Thitipramote, N.; Sangthong, S. Optimization of polysaccharide extraction from Okra (Abelmoschus esculentus) by using response surface methodology. J. Food. Sci. Agril. Technol. (JFAT) 2019, 5, 99-105, http://rs.mfu.ac.th/ojs/index.php/jfat.

21. Zengin, G.; Uysal, S.; Ceylan, R.; Aktumsek, A. Phenolic constituent, antioxidative and tyrosinase inhibitory activity of Ornithogalum narbonense L. from Turkey: a phytochemical study. Ind. Crops Prod. 2015,70, 1-6, https://doi.org/10.1016/j.indcrop.2015.03.012.

22. Yim, H. S.; Chye, F. Y.; Rao, V.; Low, J. Y.; Matanjun, P.; How, S. E.; Ho, C. W. Optimization of extraction time and temperature on antioxidant activity of Schizophyllum commune aqueous extract using response surface methodology. J. Food. Sci. Technol. 2013, 50, 275-283, https://doi.org/10.1007/s13197-011-03495.

23. Chen, X. Q.; Li, Z. H.; Wang, Z. J.; Liu, L. L.; Sun, T. T.; Ma, J. Z.; Zhang, Y. Ultrasound-assisted extraction of total anthocyanins from Rubia sylvatica Nakai fruit and radical scavenging activity of the extract. Ind.Crops Prod. 2020, 150, 112420, https://doi.org/10.1016/j.indcrop.2020.112420.

24. Los, F. G. B.; Zielinski, A. A. F.; Wojeicchowski, J. P.; Nogueira, A.; Demiate, I. M. Extraction optimization of phenolic extracts from carioca bean (Phaseolus vulgaris L.) using response surface methodology. Food Anall. Methods 2019, 12, 148-159, https://doi.org/10.1007/s12161-018-1347-2.

25. Tomšik, A.; Pavlić, B.; Vladić, J.; Ramić, M.; Brindza, J.; Vidović, S. Optimization of ultrasound-assisted extraction of bioactive compounds from wild garlic (Allium ursinum L.). Ultrason. Sonochem. 2016, 29, 502511, https://doi.org/10.1016/j.ultsonch.2015.11.005.

26. Biswas, A.; Dey, S.; Li, D.; Yiu, L.; Zhang, J.; Huang, S.; Deng, Y. Comparison of phytochemical profile, mineral content, and in vitro antioxidant activities of corchorus capsularis and corchorus olitorius leaf extracts from different populations. J. Food. Qual. 2020, https://doi.org/10.1155/2020/2931097.

27. Zielinski, A. A.; Haminiuk, C. W.; Nunes, C. A.; Schnitzler, E.; van Ruth, S. M.; Granato, D. Chemical composition, sensory properties, provenance, and bioactivity of fruit juices as assessed by chemometrics: a critical review anguideline. Compr. Rev. Food. SCI. F 2014, 13, 300-316, https://doi.org/10.1111/15414337.12060.

28. Jugreet, B. S.; Mahomoodally, M. F.; Sinan, K. I., Zengin, G.; Abdallah, H. H. Chemical variability, pharmacological potential, multivariate and molecular docking analyses of essential oils obtained from four medicinal plants. Ind.Crops Prod. 2020, 150, 112394, https://doi.org/10.1016/j.indcrop.2020.112394.

29. Li, H. Z.; Tan, Y. L.; Zhang, Z. J.; Xia, Y. Y. ; Li, X. J.; CUI, L. X. ; Chen, T. Optimization of ultrasoundassisted extraction of procyanidins from perilla seed hull and their antioxidant activities in vitro. Food. Sci. Technol. 2019, 39, 378-387,https://doi.org/10.1590/fst.30417.

30. Laib, I.; Barkat, M. Optimization of conditions for extraction of polyphenols and the determination of the 
impact of cooking on total polyphenolic, antioxidant, and anticholinesterase activities of potato. Foods 2018, 7, 36, https://doi.org/10.3390/foods7030036.

31. Gullian, K. M.; Terrats, P. M. Optimization of the ultrasound-assisted extraction of phenolic compounds from Brosimumalicastrum leaves and the evaluation of their radical-scavenging activity. Molecules 2017, 22, 1286, https://doi.org/10.3390/molecules22081286.

32. Chandrasekara, N.; Shahidi, F. Effect of roasting on phenolic content and antioxidant activities of whole cashew nuts, kernels, and testa. J. Agr. Food. Chem. 2011, 59, 5006-5014, https://doi.org/10.1021/jf2000772.

33. Yu, J.; Ahmedna, M.; Goktepe, I. Effects of processing methods and extraction solvents on concentration and antioxidant activity of peanut skin phenolics. Food. Chem. 2005, 90, 199-206, https://doi.org/10.1016/j.foodchem.2004.03.048.

34. Locatelli, M.; Travaglia, F.; Coïsson, J. D.; Martelli, A.; Stévigny, C.; Arlorio, M. Total antioxidant activity of hazelnut skin (Nocciola Piemonte PGI): Impact of different roasting conditions. Food Chemistry 2010, 119, 1647-1655, https://doi.org/10.1016/j.foodchem.2009.08.048.

35. Yin, Q.; Mu, H.; Zeng, M.; Gao, D.; Qin, F.; Chen, J.; He, Z. Effects of heating on the total phenolic content, antioxidant activities and main functional components of simulated Chinese herb candy during boiling process. J. Food. Meas. Charact. 2019, 13, 476-486, https://doi.org/10.1007/s11694-018-9961-7.

36. Kim, S. Y.; Jeong, S. M.; Park, W. P.; Nam, K. C.; Ahn, D. U.; Lee, S. C. Effect of heating conditions of grape seeds on the antioxidant activity of grape seed extracts. Food. Chem. 2006, 97, 472-479, https://doi.org/10.1016/j.foodchem.2005.05.027.

37. Lin, J. T.; Liu, S. C.; Hu, C. C.; Shyu, Y. S.; Hsu, C. Y.; Yang, D. J. Effects of roasting temperature and duration on fatty acid composition, phenolic composition, Maillard reaction degree and antioxidant attribute of almond (Prunus dulcis) kernel. Food. Chem. 2016, 190, 520-528, https://doi.org/10.1016/j.foodchem.2015.06.004.

38. Kumar, S.; Pandey, A. K. Chemistry and biological activities of flavonoids: an overview. Sci. World. J. 2013, https://doi.org/10.1155/2013/162750.

39. Jeong, S. M.; Kim, S. Y.; Kim, D. R.; Nam, K. C.; Ahn, D. U.; Lee, S. C. Effect of seed roasting conditions on the antioxidant activity of defatted sesame meal extracts. J. Food. Sci. 2004, 69, C377-C381, https://doi.org/10.1111/j.1365-2621.2004.tb10701.x.

40. Maran, J. P.; Manikandan, S.; Mekala, V. Modeling and optimization of betalain extraction from Opuntia ficus-indica using Box-Behnken design with desirability function. Ind. Crops Prod. 2013, 49, 304-311, https://doi.org/10.1016/j.indcrop.2013.05.012.

41. Youn, K. S.; Chung, H. S. Optimization of the roasting temperature and time for preparation of coffee-like maize beverage using the response surface methodology. LWT-Food. Sci. Technol. 2012, 46, 305-310, https://doi.org/10.1016/j.lwt.2011.09.014.

42. Namiki, M. Chemistry of Maillard reactions: recent studies on the browning reaction mechanism and the development of antioxidants and mutagens. Adv. Food. Res. 1988, 32, 115-184, https://doi.org/10.1016/S0065-2628(08)60287-6.

43. Yaylayan, V. A.; Kaminsky, E. Isolation and structural analysis of Maillard polymers: caramel and melanoidin formation in glycine/glucose model system. Food Chem. 1998, 63, 25-31, https://doi.org/10.1016/S0308-8146(97)00237-9.

44. Gao, P.; Cao, Y.; Liu, R.; Jin, Q.; Wang, X.. Phytochemical Content, Minor-Constituent Compositions, and Antioxidant Capacity of Screw-Pressed Walnut Oil Obtained from Roasted Kernels. Eur. J. Lipid. Sci. Tech. 2019, 121, 1800292,https://doi.org/10.1002/ejlt.201800292.

45. Nicoli, M. C.; Anese, M.; Parpinel, M. Influence of processing on the antioxidant properties of fruit and vegetables. Trends in Food Sci \& Tech 1999, 10, 94-100, https://doi.org/10.1016/S0924-2244(99)00023-0.

46. Lee, J. C.; Kim, H. R.; Kim, J.; Jang, Y. S. Antioxidant property of an ethanol extract of the stem of Opuntia ficus-indica var. saboten. J. Agrifood. Chem. 2002, 50, 6490-6496, https://doi.org/10.1021/jf020388c.

47. Hayase, F.; Hirashima, S.; Okamoto, G.; Kato, H. Scavenging of active oxygens by melanoidins. Agr. Bio. Chem. 1989, 53, 3383-3385, https://doi.org/10.1271/bbb1961.53.3383.

48. Dewanto, V.; Wu, X.; Adom, K. .K..; Liu, R. H. Thermal processing enhances the nutritional value of tomatoes by increasing total antioxidant activity. J. Agric. Food. Chem. 2002, 50, 3010-3014, https://doi.org/10.1021/jf0115589.

49. Amri, O.; Elguiche, R.; Tahrouch, S.; Zekhnini, A.; Hatimi, A. Antifungal and antioxidant activities of some aromatic and medicinal plants from the southwest of Morocco. J. Chem. Pharm. Res. 2015, 7, 672-678. 
50. Cheniany, M.; Ebrahimzadeh, H.; Vahdati, K.; Preece, J. E.; Masoudinejad, A.; Mirmasoumi, M. Content of different groups of phenolic compounds in microshoots of Juglans regia cultivars and studies on antioxidant activity. Acta. Physiol. Plant. 2013, 35, 443-450, https://doi.org/10.1007/s11738-012-1087-7. 